\title{
Introduction and perspective, historical note
}

\author{
Geoffrey Burnstock ${ }^{1,2 *}$ \\ ${ }^{1}$ Autonomic Neuroscience Centre, University College Medical School, London, UK \\ ${ }^{2}$ Department of Pharmacology, The University of Melbourne, Melbourne, VIC, Australia
}

\section{Edited by:}

Rashid Giniatullin, University of

Eastern Finland, Finland

\section{Reviewed by:}

Gennady G. Yegutkin, University of Turku, Finland

Francesco Di Virgilio, University of

Ferrara, Italy

\section{*Correspondence:}

Geoffrey Burnstock, Autonomic

Neuroscience Centre, University

College Medical School, Rowland

Hill Street, London NW3 2PF, UK

e-mail: g.burnstock@ucl.ac.uk
P2 nucleotide receptors were proposed to consist of two subfamilies based on pharmacology in 1985, named P2X and P2Y receptors. Later, this was confirmed following cloning of the receptors for nucleotides and studies of transduction mechanisms in the early 1990s. P2X receptors are ion channels and seven subtypes are recognized that form trimeric homomultimers or heteromultimers. P2X receptors are involved in neuromuscular and synaptic neurotransmission and neuromodulation. They are also expressed on many types of non-neuronal cells to mediate smooth muscle contraction, secretion, and immune modulation. The emphasis in this review will be on the pathophysiology of P2X receptors and therapeutic potential of $\mathrm{P} 2 \mathrm{X}$ receptor agonists and antagonists for neurodegenerative and inflammatory disorders, visceral and neuropathic pain, irritable bowel syndrome, diabetes, kidney failure, bladder incontinence and cancer, as well as disorders if the special senses, airways, skin, cardiovascular, and musculoskeletal systems.

\section{Keywords: brain, skin, lung, gut, bladder, cancer, pain, inflammation}

\section{INTRODUCTION}

Division of receptors for purines into P1 (adenosine) and P2 (ATP/ADP) families was proposed in 1978 (Burnstock, 1978). In 1985, P2 receptors were divided into two subtypes, P2X and $\mathrm{P} 2 \mathrm{Y}$ receptors, on the basis of pharmacology (Burnstock and Kennedy, 1985). In the early 1990's, P2 receptors for purines and pyrimidines were cloned and characterized and second messenger mechanisms determined (see Abbracchio and Burnstock, 1994; Ralevic and Burnstock, 1998). P2Y (Webb et al., 1993) and $\mathrm{P}_{2} \mathrm{Y}_{2}$ (Lustig et al., 1993) G protein-coupled receptors were described initially and soon after P2X1 and P2X2 ion channel receptors were reported (Brake et al., 1994; Valera et al., 1994). Seven P2X receptor subunits have been identified. P2X receptors have been cloned from many eukaryotic species, including mammals, fish, parasitic trematode worms, amoeba, slime mould, and green algae (see Fountain and Burnstock, 2009; Burnstock and Verkhratsky, 2012a). The physiology and pathophysiology of $\mathrm{P} 2 \mathrm{X}$ receptors in diseases of the special senses, urinary tract, gastrointestinal tract, pancreas, skin, and musculoskeletal system, as well as in cancer and inflammatory disorders will be discussed.

It was assumed for a long time that the main source of ATP acting on purinoceptors was damaged or dying cells. It is now clear, however, that ATP is released, without causing damage, from many cell types, including endothelial and urothelial cells, macrophages, astrocytes, odontoblasts and osteoblasts, in response to gentle mechanical disturbance, hypoxia, and some agents (Bodin and Burnstock, 2001; Lazarowski et al., 2011; Lazarowski, 2012). Release of ATP initiates purinergic mechanosensory transduction that is involved in bone remodeling (Orriss et al., 2010) and visceral pain via P2X3 receptors on nociceptive sensory nerves (Burnstock, 1999, 2007b). The mechanism of ATP transport from cells appears to be a combination of vesicular exocytosis and connexin and/or pannexin 1 hemichannels (see Lazarowski, 2012). Ectoenzymes are involved in the breakdown of released ATP into ADP, AMP, adenosine, inosine and hypoxanthine (see Zimmermann, 2006; Yegutkin, 2008). These enzymes include NTPDases, pyrophosphatase/phosphodiesterases, alkaline phosphatases, $5^{\prime}$ - nucleotidase and monoamine oxidase.

\section{P2X RECEPTOR SUBTYPES}

Seven P2X subunits have been cloned and characterized. The $\mathrm{P} 2 \mathrm{X} 1$ to P2X6 receptors are 379-472 amino acids long, while the $\mathrm{P} 2 \mathrm{X} 7$ receptor is 595 amino acids long, due to the increased length of the $\mathrm{COOH}$ terminus. The molecular physiology of $\mathrm{P} 2 \mathrm{X}$ receptors has been thoroughly reviewed (see North, 2002). Each subunit possesses two hydrophobic, transmembrane spanning regions that span the cell plasma membrane. A seminal study has been published describing the crystal structure of the P2X4 receptor (Gonzales et al., 2009; Kawate et al., 2009). When P2X7 receptors are occupied by ATP, cation channels are activated, but in addition with high concentrations of ATP large pores are formed which lead to uptake of $\mathrm{Ca}^{2+}$ leading to apoptotic cell death.

The seven P2X subtypes combine as trimers (Nicke et al., 1998), which form functional homo- and heteromultimers (see Burnstock, 2007a). P2X6 receptors do not form a homomultimer, while $\mathrm{P} 2 \mathrm{X} 7$ receptors do not form a heteromultimer. $\mathrm{P} 2 \mathrm{X} 1 / 2$, $\mathrm{P} 2 \mathrm{X} 1 / 4, \mathrm{P} 2 \mathrm{X} 1 / 5, \mathrm{P} 2 \mathrm{X} 2 / 3, \mathrm{P} 2 \mathrm{X} 2 / 6$, and $\mathrm{P} 2 \mathrm{X} 4 / 6$ heteromultimers have been identified.

\section{DISTRIBUTION OF P2X RECEPTORS}

Detailed analyses of the distribution of $\mathrm{P} 2 \mathrm{X}$ receptors on nerves and non-neuronal cells have been published (Burnstock and Knight, 2004; Burnstock, 2007b; see Table 1).

\section{PHYSIOLOGY OF P2X RECEPTORS}

ATP released as a cotransmitter with noradrenaline (NA) from sympathetic nerves was shown to act mainly via $\mathrm{P} 2 \mathrm{X} 1$ receptors 
Table 1 | Principal P2X receptors expressed by excitable tissues and non-neuronal cells (Compiled from Burnstock, 2007b).

\section{NEURONAL}

Sympathetic neurons

Parasympathetic neurons

Sensory neurons

Enteric neurons

Central nervous system

Retinal neurons

\section{MUSCLE CELLS}

Smooth muscle

Skeletal muscle

-Developing

-Adult

Cardiac muscle

\section{NON-NEURONAL}

Osteoblasts

Osteoclasts

Cartilage

Keratinocytes

Fibroblasts

Adipocytes

Epithelial cells (lung,

kidney, trachea, uterus,

cornea)

Astrocytes

Oligodendrocytes

Microglia

Müller cells

Enteric glial cells

Sperm

Endothelial cells

Erythrocytes

Platelets

Immune cells

(thymocytes,

macrophages,

neutrophils, eosinophils, lymphocytes, mast cells, dendritic cells)

Exocrine secretary cells

Endocrine secretory cells (pituitary, pancreas,

adrenal, thyroid, testis)

Cholangiocytes

Interstitial cells of Cajal

Kupffer cells

Special senses

Inner ear

Eye

Tongue

Olfactory organ

Cochlea hair cells
P2X1-7

P2X2, P2X3, P2X4, P2X5

$\mathrm{P} 2 \mathrm{X} 1-7$, predominantly $\mathrm{P} 2 \mathrm{X} 3$ and $\mathrm{P} 2 \mathrm{X} 2 / 3$

$\mathrm{P} 2 \mathrm{X} 2, \mathrm{P} 2 \mathrm{X} 3, \mathrm{P} 2 \mathrm{X} 4, \mathrm{P} 2 \mathrm{X} 7$

$\mathrm{P} 2 \mathrm{X} 2, \mathrm{P} 2 \mathrm{X} 4$ and $\mathrm{P} 2 \mathrm{X} 6$ (perhaps

heteromultimers) predominate, (P2X7?)

P2X2, P2X3, P2X4, P2X5, P2X7

P2X1-7, predominantly P2X1

P2X2, P2X5, P2X6

$\mathrm{P} 2 \mathrm{X} 1-7$

P2X1, P2X3, P2X4, P2X5, P2X6

$P 2 X 1, P 2 X 2, P 2 X 5, P 2 X 7$

$P 2 X 1, P 2 X 2, P 2 X 4, P 2 X 7$

$\mathrm{P} 2 \mathrm{X} 2$

$\mathrm{P} 2 \mathrm{X} 2, \mathrm{P} 2 \mathrm{X} 3, \mathrm{P} 2 \mathrm{X} 5, \mathrm{P} 2 \mathrm{X} 7$

$\mathrm{P} 2 \mathrm{X} 7$

$\mathrm{P} 2 \mathrm{X} 1$

$P 2 X 4, P 2 X 5, P 2 X 6, P 2 X 7$

P2X1-7

$\mathrm{P} 2 \mathrm{X} 1$

$\mathrm{P} 2 \mathrm{X} 4, \mathrm{P} 2 \mathrm{X} 7$

$\mathrm{P} 2 \mathrm{X} 3, \mathrm{P} 2 \mathrm{X} 4, \mathrm{P} 2 \mathrm{X} 5, \mathrm{P} 2 \mathrm{X} 7$

$\mathrm{P} 2 \times 7$

$\mathrm{P} 2 \mathrm{X} 2, \mathrm{P} 2 \mathrm{X} 7$

$\mathrm{P} 2 \mathrm{X} 1, \mathrm{P} 2 \mathrm{X} 2, \mathrm{P} 2 \mathrm{X} 3$, predominately $\mathrm{P} 2 \mathrm{X} 4$

$P 2 X 2, P 2 X 4, P 2 X 7$

$\mathrm{P} 2 \mathrm{X} 1$

$\mathrm{P} 2 \mathrm{X} 4$ and predominately $\mathrm{P} 2 \mathrm{X} 7$, but some

P2X1, P2X2, P2X5

P2X1, P2X4, P2X7

$\mathrm{P} 2 \mathrm{X} 1-7$, predominately $\mathrm{P} 2 \mathrm{X} 2 / 6$

$\mathrm{P} 2 \mathrm{X} 2, \mathrm{P} 2 \mathrm{X} 3, \mathrm{P} 2 \mathrm{X} 4, \mathrm{P} 2 \mathrm{X} 6$

$\mathrm{P} 2 \mathrm{X} 2, \mathrm{P} 2 \mathrm{X} 5$

$P 2 X 1, P 2 X 4, P 2 X 7$

$\mathrm{P} 2 \mathrm{X} 1, \mathrm{P} 2 \mathrm{X} 2, \mathrm{P} 2 \mathrm{X} 3, \mathrm{P} 2 \mathrm{X} 7$

$\mathrm{P} 2 \times 2, \mathrm{P} 2 \times 7$

$\mathrm{P} 2 \mathrm{X} 2, \mathrm{P} 2 \mathrm{X} 3$

$\mathrm{P} 2 \mathrm{X} 2, \mathrm{P} 2 \mathrm{X} 4$

$P 2 X 1, P 2 X 2, P 2 X 7$ on both visceral and vascular smooth muscle to produce contractions (see Burnstock, 1990, 2009b) and ATP released together with acetylcholine (ACh) from parasympathetic nerves acts on P2X1 receptors in the urinary bladder (Burnstock et al., 1978; Burnstock, 2013). ACh acting via nicotinic receptors was established early as the neurotransmitter released from motor nerves supplying adult skeletal muscle, but later it was shown that during postnatal development of the neuromuscular junction, ATP is released as a cotransmitter together with ACh to act on P2X receptors (see Henning, 1997). An important advance was made when purinergic synaptic transmission between nerves was described in both the coeliac ganglion (Evans et al., 1992; Silinsky et al., 1992) and medial habenula in the brain (Edwards et al., 1992).

$\mathrm{P} 2 \mathrm{X}$ receptors have also been shown to act presynaptically, for example P2X3 receptors on primary afferent sensory nerve endings in the dorsal spinal cord to enhance the release of glutamate (Gu and MacDermott, 1997) and on P2X receptors on sympathetic nerve varicosities in the vas deferens to enhance the release of NA (Queiroz et al., 2003).

$\mathrm{P} 2 \mathrm{X} 3$ homomultimer and $\mathrm{P} 2 \mathrm{X} 2 / 3$ heteromultimer receptors were identified on sensory neurons and nerve endings (Chen et al., 1995; Lewis et al., 1995) mediating both physiological reflex responses as well as nociception (see Burnstock and Verkhratsky, 2012b).

There is a wide distribution of $\mathrm{P} 2 \mathrm{X} 2, \mathrm{P} 2 \mathrm{X} 3, \mathrm{P} 2 \mathrm{X} 2 / 3, \mathrm{P} 2 \mathrm{X} 4$, and $\mathrm{P} 2 \mathrm{X} 7$ receptors in the myenteric and submucous plexuses and on intrinsic and extrinsic sensory nerves of the enteric nervous system (see Burnstock, 2008b and Figure 1). These receptors are involved in reflex activities, including modulation of peristaltic reflexes (Bian et al., 2003; Wynn et al., 2003).

Expression of most P2X receptor subtypes have been localized in different regions of the central nervous system (CNS). Sensory nerves in the brain stem expressing P2X3 receptors and $\mathrm{P} 2 \mathrm{X} 2, \mathrm{P} 2 \mathrm{X} 4$, and P2X6 receptors, mostly in the form of heteromultimers, appear to be involved in both neurotransmission and neuromodulation (see Burnstock, 2007b; Burnstock et al., 2011b; Burnstock and Verkhratsky, 2012b; Lalo et al., 2012). The role of P2X7 receptors in the CNS is controversial. Behavioral studies have implicated roles for P2X receptors in memory and learning, sleep, locomotion and feeding (see Burnstock et al., 2011a).

In the heart, $\mathrm{P} 2 \mathrm{X} 1 / 3 / 4 / 5 / 6$ receptor $\mathrm{mRNA}$ and protein are expressed in ventricles and P2X1-6 in atria (Hansen et al., 1999) leading to increase in contractility of cardiac myocytes (Shen et al., 2007). P2X receptor subtypes are widely expressed in different sites in the kidney (see Unwin et al., 2003). Preglomerular arterioles express $\mathrm{P} 2 \mathrm{X} 1$ receptors, while glomerular mesangial cells express P2X4, P2X5, and P2X7 receptors, and podocytes express P2X1 and P2X7 receptors. Different regions of the kidney tubule are immunoreactive for P2X receptors: P2X1, P2X4, P2X5, and $\mathrm{P} 2 \mathrm{X} 6$ on proximal tubules, $\mathrm{P} 2 \mathrm{X} 4$ and $\mathrm{P} 2 \mathrm{X} 6$ on distal tubules and P2X1, P2X4/6, and P2X5 on collecting ducts (Bailey and Shirley, 2009). In the collecting ducts P2X4 and P2X4/6 receptors are involved in control of sodium transport (Wildman et al., 2009).

Uptake of organic cations is mediated by $\mathrm{P} 2 \mathrm{X} 1$ and $\mathrm{P} 2 \mathrm{X} 7$ receptors in canine erythrocytes (Stevenson et al., 2009). The role 


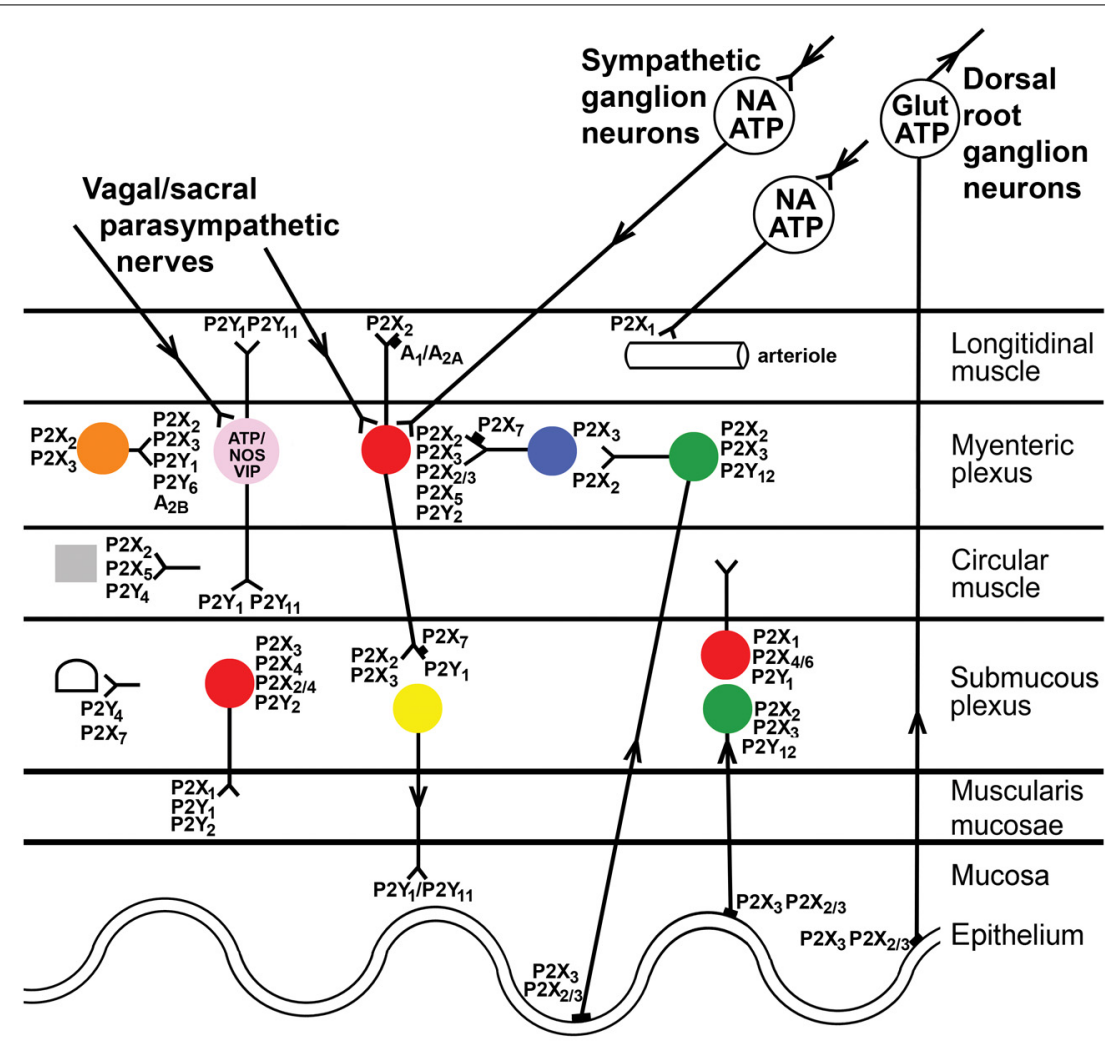

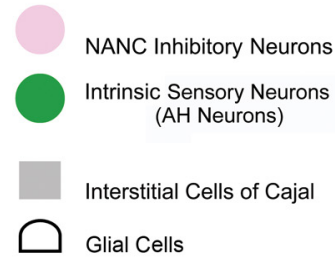

FIGURE 1 | Distribution of $\mathrm{P} 2 \mathrm{X}$ receptor subtypes in the gut Extrinsic vagal and sacral parasympathetic nerves connect with NANC inhibitory neurons in the myenteric plexus expressing P2X2 and P2X3 receptors, as well as with cholinergic motor neurons; these neurons are also activated by descending interneurons. Extrinsic sympathetic nerves modulate motility via excitatory motor neurons and constrict blood vessels in the gut via P2X1 receptors. Extrinsic sensory nerves arise from cell bodies in dorsal root ganglia and with subepithelial terminals expressing $\mathrm{P} 2 \mathrm{X} 3$ and $\mathrm{P} 2 \mathrm{X} 2 / 3$ receptors and mediate nociception.

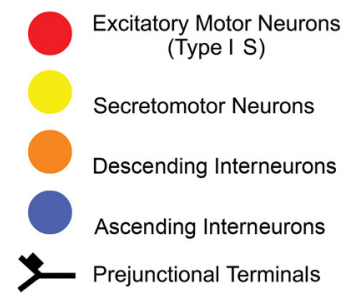

Intrinsic sensory neurons in both myenteric and submucosal plexuses express $\mathrm{P} 2 \mathrm{X} 2$ and $\mathrm{P} 2 \mathrm{X} 3$ receptors; they connect with motor pathways involved in peristalsis. Excitatory motor neurons express P2X2, P2X3, $\mathrm{P} 2 \mathrm{X} 2 / 3$, and $\mathrm{P} 2 \mathrm{X} 5$ receptors and connect with both interneurons and secretomotor neurons. Interneurons express P2X2 and P2X3 receptors. Enteric glial cells express P2X7 receptors, while interstitial cells of Cajal express $\mathrm{P} 2 \mathrm{X} 2$ and $\mathrm{P} 2 \mathrm{X} 5$ receptors. $\mathrm{P} 2 \mathrm{X} 7$ receptors appear to act as prejunctional modulators of both motor and interneurons. [Modified from Burnstock (2008c), with permission from the BMJ Publishing Group Ltd]. of the P2X1 receptor expressed by platelets is unclear, although in P2X1 knockout mice there is a decreased level of thrombus formation and increased bleeding times (Nurden, 2007). P2X1 receptors have also been claimed to play a role in sensing bacteria (Kälvegren et al., 2010).

The P2X7 receptor is involved in immunomodulation responding to extracellular ATP at sites of inflammation and tissue damage (see Di Virgilio, 2013). P2X1 receptors promote neutrophil chemotaxis and play a significant role in host defense (Lecut et al., 2009). P2X7 receptors mediate cytokine release and chemokine expression via $\mathrm{P} 2 \mathrm{X} 1$ and $\mathrm{P} 2 \mathrm{X} 3$ receptors in mouse mast cells (Bulanova et al., 2009). P2X7 receptors in human dendritic cells mediate the release of tissue factor-bearing microparticles (Baroni et al., 2007).

Keratinocyte turnover in skin epidermis involves $\mathrm{P} 2 \mathrm{X}$ receptors while $\mathrm{P}_{2} \mathrm{Y}_{1}$ and $\mathrm{P}_{2} \mathrm{Y}_{2}$ receptors in basal and parabasal layers mediate cell proliferation, $\mathrm{P} 2 \mathrm{X} 5$ receptors in the granular layer mediate cell differentiation and P2X7 receptors at the stratum granulosum/stratum corneum border mediate apoptotic cell death (Greig et al., 2003c; Burnstock et al., 2012b). In the endocrine system, the posterior pituitary expresses protein for P2X2 and P2X6 receptors and P2X2, P2X3, P2X4, and $\mathrm{P} 2 \mathrm{X} 7$ receptor channels are present on anterior pituitary cells and mediate hormone secretion (Stojilkovic et al., 2010). P2X7 
receptors are expressed on osteoblasts, enhancing differentiation and bone formation and also on osteoclasts mediating apoptosis (see Orriss et al., 2010, 2012).

$\mathrm{P} 2 \mathrm{X}$ receptors in the special senses mediate a variety of different functions (see Housley et al., 2009; Burnstock and Verkhratsky, 2012b). Nasal epithelium expresses P2X2, P2X5, and P2X7 receptors (Gayle and Burnstock, 2005), P2X1, P2X2, P2X3, and $\mathrm{P} 2 \mathrm{X} 2 / 3$ are prominent receptors in the tongue (Bo et al., 1999) mediating both taste sensation and pain (Rong et al., 2000), and $\mathrm{P} 2 \mathrm{X}$ receptors have multiple roles in the eye (see Pintor, 2006) and inner ear (see Housley and Gale, 2010).

\section{PATHOPHYSIOLOGY OF P2X RECEPTORS}

The involvement of $\mathrm{P} 2 \mathrm{X}$ receptors is being investigated increasingly in relation to a wide variety of diseases (see Burnstock, 2006a,b, 2007b, 2008a).

\section{DISEASES OF SPECIAL SENSES}

$\mathrm{P} 2 \mathrm{X}$ receptors are expressed by various structures in the eye and novel therapeutic strategies are being developed for glaucoma, dry eye, and retinal detachment (Pintor et al., 2003). P2X7 receptors are increased in retinal microvessels early in experimental diabetes. This suggests that purinergic vasotoxicity may play a role in microvascular cell death, characteristic of diabetic retinopathy (Sugiyama et al., 2004).

P2X receptors have been described in the vestibular system (Xiang et al., 1999), in particular on the endolymphatic surface of the cochlear endothelium, an area associated with sound transduction. It has been suggested that ATP may regulate fluid homeostasis, cochlear blood flow, hearing sensitivity and development, and therefore may be useful for the treatment of Ménière's disease, tinnitus, and sensorineural deafness (Housley, 2000). There is upregulation of $\mathrm{P} 2 \mathrm{X} 2$ receptors in the cochlear occurs during sustained loud noise. $\mathrm{P} 2 \mathrm{X} 2$ receptor expression is also increased in spiral ganglion neurons (Wang et al., 2003).

Purinergic receptors have been described in the nasal mucosa, including the expression of $\mathrm{P} 2 \mathrm{X} 3$ receptors on olfactory neurons (Gayle and Burnstock, 2005). The induction of heat-shock proteins by noxious odor damage is prevented by the administration in vivo of P2 receptor antagonists (Hegg and Lucero, 2006).

\section{DISEASES OF THE KIDNEY AND URINARY TRACT}

Purinoceptors are expressed in different regions of the nephron, the glomerulus, and renal vascular system in the kidney and different subtypes are involved in the regulation of renin secretion, glomerular filtration and the transport of water, ions, nutrients and toxins (Unwin et al., 2003). Autocrine purinergic signaling enhances cyst expansion and accelerates progression of polycystic kidney disease (Schwiebert et al., 2002). P2X7 receptor expression is increased in cystic tissue from a rat model of autosomal dominant polycystic kidney disease (Turner et al., 2004). Increased glomerular expression of $\mathrm{P} 2 \mathrm{X} 7$ receptors has been reported in rat models of glomerular injury due to diabetes and hypertension (Vonend et al., 2004). Human and experimental glomerulonephritis also showed increase in P2X7 receptor expression in the glomerulus (Turner et al., 2007).

$\mathrm{P} 2 \mathrm{X} 3$ receptors are expressed by the suburothelial sensory nerves, and both the human and guinea-pig ureter urothelial cells release ATP in a pressure-dependent fashion when the ureter is distended (Knight et al., 2002; Calvert et al., 2008). P2X3 antagonists may be useful to alleviate renal colic (Rong and Burnstock, 2004).

Atropine will block at least $95 \%$ of parasympathetic nervemediated contraction in the healthy human bladder, showing neurotransmission that is predominantly cholinergic, although $\mathrm{P} 2 \mathrm{X} 1$ receptors are present on the smooth muscle (Burnstock, 2001a). However, the purinergic component of parasympathetic cotransmission is increased in pathological conditions (see Burnstock, 2013). It is increased to $40 \%$ in interstitial cystitis, outflow obstruction, idiopathic detrusor instability and most types of neurogenic bladder. Release of ATP from distended bladder urothelial cells in patients with interstitial cystitis is significantly greater than from healthy cells (Tempest et al., 2004) and P2X1 receptor subtype expression is increased in obstructed bladder (Boselli et al., 2001).

Purinergic signaling also plays a role in afferent sensation from the bladder, involved in both the micturition reflex and pain. Release of ATP from urothelial cells occurs during distension (Vlaskovska et al., 2001) and it acts on P2X3 receptors on suburothelial sensory nerve endings (Cockayne et al., 2000). P2X3 receptors are therefore a potential target for pharmacological manipulation in the treatment of both pain and detrusor instability. In idiopathic detrusor instability, there is abnormal purinergic transmission in the bladder ( $O$ 'Reilly et al., 2002). Voiding dysfunction involves P2X3 receptors in conscious chronic spinal cord injured rats, suggesting that $\mathrm{P} 2 \mathrm{X} 3$ antagonists might also be useful for the treatment of neurogenic bladder (Lu et al., 2002). Drugs that alter ATP release or breakdown might also be considered as therapeutic targets (Chess-Williams, 2004). A recent review about purinergic signaling in the lower urinary tract is available (Burnstock, 2013).

\section{CARDIOVASCULAR DISEASES}

There is up-regulation of $\mathrm{P} 2 \mathrm{X} 1$ receptor mRNA in the hearts of rats with congestive heart failure and an increase in expression of $\mathrm{P} 2 \mathrm{X} 1$ receptors in the atria of patients suffering from dilated cardiomyopathy. $\mathrm{P} 2 \mathrm{X} 4$ receptor $\mathrm{mRNA}$ was reported to be upregulated in ligation-induced heart failure and was claimed to have a beneficial life-prolonging role (Musa et al., 2009).

ATP, released as the purinergic component of sympathetic cotransmission, is increased in spontaneously hypertensive rats mediating vasoconstriction via P2X1 receptors (see Ralevic and Burnstock, 1998). There is upregulation of placental P2X4 receptors in mild preeclampsia (Roberts et al., 2007).

\section{DISORDERS OF THE GUT}

$\mathrm{P} 2 \mathrm{X}$ receptors play major roles in diseases of the gut (see Burnstock, 2008a,b). P2X7 receptors, that mediate cytokine production, may play a role in the response of enteric glia to inflammation (Vanderwinden et al., 2003). Enhancement of P2X3 receptor-mediated purinergic signaling in an animal model of colitis has been described (Wynn et al., 2004). P2X3 receptor expression is also increased in the enteric plexuses in human irritable bowel syndrome (IBS), suggesting a role in dysmotility and pain initiation (Yiangou et al., 2001; Galligan, 2004; Shinoda 
et al., 2009). Visceral hyperalgesia induced in a rat model of IBS was associated with potentiation of ATP-evoked responses and an enhanced expression of $\mathrm{P} 2 \mathrm{X} 3$ receptors in sensory neurons in the colon (Xu et al., 2008). In aganglionic bowel from Hirschsprung's disease patients, P2X3 immunohistochemistry was demonstrated, suggesting that the sensory nerves may be involved (Facer et al., 2001).

Both intrinsic sensory neurons in the submucous plexus of the gut and extrinsic sensory nerves with cell bodies in the dorsal root ganglia (DRG), show positive immunoreactivity for P2X3 receptors (Xiang and Burnstock, 2004). It has been suggested that during moderate distension, low threshold intrinsic enteric sensory fibers are activated, via $\mathrm{P} 2 \mathrm{X} 3$ receptors, by ATP released from mucosal epithelial cells resulting in reflexes concerned with propulsion of material down the gut (Burnstock, 2001b). Peristalsis is impaired in the small intestine of mice lacking the $\mathrm{P} 2 \mathrm{X} 3$ receptor subunit, which supports this view (Bian et al., 2003). During substantial (colic) distension associated with nociception, higher threshold extrinsic sensory fibers may be activated by ATP released from the mucosal epithelial cells to pass messages through the DRG to pain centers in the CNS (Wynn et al., 2003, 2004). Sensitization of P2X3 receptors on vagal and spinal afferents in the stomach have been claimed to contribute to dyspeptic symptoms and to the development of visceral hyperalgesia (Dang et al., 2005). A recent review describing $\mathrm{P} 2 \mathrm{X}$ receptors in the gut is available (Burnstock, 2012).

\section{DISEASES OF THE REPRODUCTIVE SYSTEM}

ATP induces a significant increase in sperm fertilizing potential and this has led to the use of ATP for treatment of spermatozoa during in vitro fertilization (Rossato et al., 1999). P2X1 receptor knockout mice appear normal, but fail to breed and this is associated with loss of the purinergic component of sympathetic cotransmission in the vas deferens (Dunn, 2000; Mulryan et al., 2000). P2X receptor subtypes are expressed at different stages during spermatogenesis in the adult rat testis, which may be novel targets for both fertility and contraception (Glass et al., 2001).

Low concentrations of ATP stimulate changes in transepithelial conductance in the human uterine cervix, the first phase mediated by $\mathrm{P}_{2} \mathrm{Y}_{2}$ receptors and the second phase by $\mathrm{P} 2 \mathrm{X} 4$ receptors (Gorodeski, 2002).

\section{DIABETES}

There is an enhancement of P2X7 receptor-induced pore formation and apoptosis in early diabetes in the retinal microvasculature (Sugiyama et al., 2004). P2X7 receptors are located on glucagon-containing $\alpha$ cells in pancreatic islets (Coutinho-Silva et al., 2001). In streptozotocin-diabetic rats P2X7 receptor-labeled $\alpha$ cells migrate centrally to take the place of the insulin-containing $\beta$ cells, although the functional significance of this is unknown (Coutinho-Silva et al., 2003). Central neuropathic complications occur in diabetic neuropathy, including decreased cognitive performance and it has been shown that synaptic ATP signaling is depressed in streptozotocin-induced diabetic rats (Duarte et al., 2007). The density of $\mathrm{P} 2 \mathrm{X} 3 / 5 / 7$ receptors was decreased in the hippocampal nerve terminals of diabetic rats. A recent review of the literature concerned with purinergic signaling in diabetes is available (Burnstock and Novak, 2013).

\section{DISEASES OF THE AIRWAYS}

Lung epithelial cells express P2X4 receptors that are involved in regulation of ciliary beat, manipulation of which may be of therapeutic benefit for cystic fibrosis (Zsembery et al., 2003). Vagal afferent purinergic signaling may be involved in the hyperactivity associated with asthma and chronic obstructive pulmonary disease (Adriaensen and Timmermans, 2004). Erythromycin, used for the treatment of upper and lower respiratory tract infections, blocks P2X receptor-mediated $\mathrm{Ca}^{2+}$ influx and may be involved in its anti-secretory effects in the treatment of chronic respiratory tract infections (Zhao et al., 2000).

A network of respiratory neurons in the ventrolateral medulla (VLM) is responsible for the generation of the respiratory rhythm and also functions as a chemoreceptive area mediating the ventilating response to hypercapnia. ATP acting via P2X2 receptors expressed on VLM neurons is involved in these functions (Gourine et al., 2003). P2 receptor synaptic signaling in respiratory motor control has been implicated by the multiple physiological effects of ATP in hypoglossal activity mediated by $\mathrm{P} 2 \mathrm{X} 2, \mathrm{P} 2 \mathrm{X} 4$, and $\mathrm{P} 2 \mathrm{X} 6$ receptors in the nucleus ambiguous and the hypoglossal nucleus (Collo et al., 1996). ATP injected into the caudal nucleus of the solitary tract of awake rats produced respiratory responses (Antunes et al., 2005).

P2X7 receptors are expressed in alveolar macrophages, which play a pivotal role in the development of chronic lung inflammatory reactions, such as idiopathic pulmonary fibrosis, silicosis, asbestosis, hypersensitivity pneumonitis, sarcoidosis and mycobacterium tuberculosis (Lemaire and Leduc, 2004). Stimulation of P2X7 receptors results in activation of the proinflammatory interleukin (IL)-1 to IL-5 cytokine cascade and the formation of multinucleated giant cells, a hallmark of granulomatous reactions. A recent review describing purinergic signaling in the airways in health and disease has been published recently (Burnstock et al., 2012a).

\section{DISEASES OF SKIN}

An increase of $\mathrm{P} 2 \mathrm{X} 3$ and $\mathrm{P} 2 \mathrm{X} 2 / 3$ nociceptive receptors on sensory nerve endings in inflamed skin has been reported and antagonists are being explored as analgesics (Hamilton et al., 2001). A pathogenic role for keratinocyte-derived ATP in irritant dermatitis has been suggested (Mizumoto et al., 2003). There are changes in expression of purinergic receptors in the regenerating epidermis in wound healing (Greig et al., 2003a). Acceleration of skin barrier repair and prevention of epidermal hyperplasia induced by skin barrier disruption by $\mathrm{P} 2 \mathrm{X}$ receptor antagonists has been reported (Denda et al., 2002). A review about purinergic signaling in skin in health and disease is available (Burnstock et al., 2012b).

\section{IMMUNE SYSTEM AND INFLAMMATION}

P2X7 receptors expressed by inflammatory and immune cells play a pivotal role in inflammation and immunomodulation (Di Virgilio, 2007, 2013). The treatment of neurogenic inflammation, rheumatoid arthritis, and periodontitis by purinergic compounds is being explored. P2X7 receptor-mediated apoptosis in macrophages results in killing of the mycobacteria 
contained within them, unlike the macrophage apoptosis produced by other agents (Lammas et al., 1997). There is accumulation of macrophages expressing $\mathrm{P} 2 \mathrm{X} 4$ receptors in rat CNS lesions during experimental autoimmune encephalomyelitis (Guo and Schluesener, 2005). It has been suggested that ATP may be mechanistically involved in human allergic/asthmatic reactions (Schulman et al., 1999). P2X7 receptors are expressed by alveolar macrophages, which, when activated, trigger proinflammatory activation of IL1-6 cytokines and granulomatous reactions (Lemaire and Leduc, 2004). A lower concentration of ATP activation of $\mathrm{P} 2 \mathrm{X} 7$ receptors can result in cell proliferation (Di Virgilio et al., 2009). The functional expression of P2X7 receptors on $\mathrm{B}$ lymphocytes may be related to the severity of B-cell chronic lymphocytic leukaemia (Adinolfi et al., 2002).

ATP induces cell death in $\mathrm{CD} 4^{+} / \mathrm{CD}^{+}$double-positive thymocytes during the acute phase of Trypanosoma cruzi infection in Chaga's disease and may play a role in the thymus atrophy that occurs in Chaga's disease (Mantuano-Barradas et al., 2003). Schistosoma mansoni, a parasitic blood fluke, also produces thymic atrophy, and the $\mathrm{P} 2 \mathrm{X}$ receptor cloned from S. mansoni provided an example of a non-vertebrate ATP-gated ion channel and suggests a drug target for the treatment of schistosomiasis (Agboh et al., 2004).

\section{CANCER}

The use of adenine nucleotides as anticancer agents was first described by Rapaport (1983). ATP, injected intraperitoneally into tumor-bearing mice, resulted in anticancer activity against several fast-growing aggressive carcinomas (Agteresch et al., 2003). Evidence has been presented that extracellular ATP inhibits the growth of a variety of human tumors, including prostate, bladder, breast, colon, liver, ovarian, colorectal, oesophageal and melanoma cancer cells, partly via $\mathrm{P} 2 \mathrm{X} 7$ receptors mediating apoptotic cancer cell death (Abraham et al., 2003; White and Burnstock, 2006). Studies have been carried out to determine

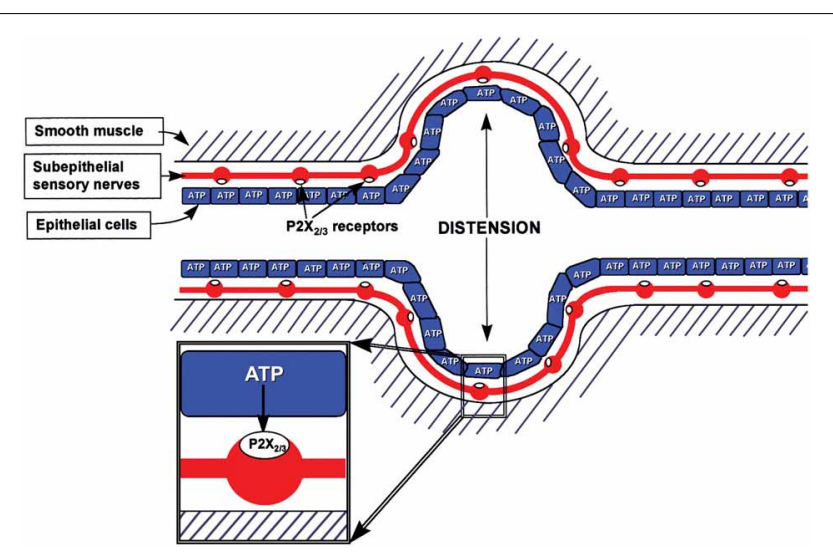

FIGURE 2 | Schematic representation of hypothesis for purinergic mechanosensory transduction in tubes (e.g., ureter, vagina, salivary and bile ducts, gut) and sacs (e.g., urinary and gall bladders, lung). It is proposed that distension leads to release of ATP from epithelium lining the tube or sac, which then acts on $\mathrm{P} 2 \mathrm{X}_{3}$ and/or $\mathrm{P} 2 \mathrm{X}_{2 / 3}$ receptors on subepithelial sensory nerves to convey sensory/nociceptive information to the CNS. [Reproduced from Burnstock (1999), with permission from Wiley]. the $\mathrm{P} 2$ receptor subtypes that contribute to ATP suppression of malignant melanomas (White et al., 2005a,b), basal and squamous cell tumors (Greig et al., 2003b) and prostate and bladder cancers (Calvert et al., 2004; Shabbir et al., 2008a,b). P2X5 receptors mediate cell differentiation, which in effect is antiproliferative and apoptotic cell death is mediated by $\mathrm{P} 2 \mathrm{X} 7$ receptors. A review has been published recently entitled "Purinergic signaling and cancer" (Burnstock and Di Virgilio, 2013).

\section{MUSCULOSKELETAL DISEASES}

Purinergic signaling is involved in bone development and remodeling (Hoebertz et al., 2003; Burnstock and Arnett, 2006; Orriss et al., 2010). Osteoclasts, osteocytes, osteoblasts and chondrocytes all express $\mathrm{P} 2 \mathrm{X}$ receptors. Regulatory roles in bone formation and resorption by $\mathrm{P} 2 \mathrm{X} 7$ receptors were revealed by studies of $\mathrm{P} 2 \mathrm{X} 7$ receptor knockout mice. The purinoceptors on bone and cartilage represent potential targets for the development of novel therapeutics to inhibit bone resorption in musculoskeletal diseases, including rheumatoid arthritis, osteoporosis, tumor-induced osteolysis, and periodontitis (Komarova et al., 2001). The P2X7 receptor antagonist, oxidized ATP, reduced inflammatory pain in arthritic rats (Dell'Antonio et al., 2002).

Lymphoblastoid cells from Duchenne muscular dystrophy patients are sensitive to stimulation by extracellular ATP (Ferrari et al., 1994). Evidence has been presented for a role for P2X receptor-mediated signaling in muscle regeneration using the $m d x$ mouse model of muscular dystrophy, which raised the possibility of new therapeutic strategies for the treatment of muscle disease (Ryten et al., 2004). A recent review about purinergic signaling in the musculoskeletal system is available (Burnstock et al., 2013).

\section{DISORDERS OF THE CENTRAL NERVOUS SYSTEM}

Recent reviews have focused on purinergic signaling in disorders of the CNS (Burnstock, 2008a; Burnstock et al., 2011a; Franke et al., 2012; Volonté and Burnstock, 2012).

Microglia and macrophages expressing P2X4 receptors accumulate following experimental traumatic brain injury and spinal cord injury. Activated microglia also show increase in P2X7 receptor expression, which initiate microglial proliferation and death. Lesions in the cerebellum result in upregulation of P2X1 and $\mathrm{P} 2 \mathrm{X} 2$ receptors in precerebellar nuclei, and there is increased expression of several subtypes of $\mathrm{P} 2 \mathrm{X}$ receptors after stab wound injury in the nucleus accumbens (Franke et al., 2006). P2X7 receptors are upregulated following ischaemia on neurons and glial cells in rat cerebral cortex, and become supersensitive in cerebrocortical cell cultures (Cavaliere et al., 2003). Ischaemic cell death was prevented by $\mathrm{P} 2$ receptor antagonists.

Involvement of $\mathrm{P} 2 \mathrm{X}$ receptors in neurodegenerative diseases such as Parkinson's, Alzheimer's, Huntington's, amyotrophic lateral sclerosis (ALS) and multiple sclerosis (MS) has been described (see Burnstock, 2008a). In the pathogenesis of Parkinson's disease, release of ATP from disrupted cells may cause cell death in neighboring cells expressing P2X7 receptors, leading to a necrotic volume increase. Upregulation of P2X7 receptors in human Alzheimer's diseased brains and in animal models has been reported (Parvathenani et al., 2003; McLarnon et al., 
2006) and stimulation of P2X7 receptors on human microglia and macrophages increased the degenerative lesions observed in Alzheimer's disease. In two different transgenic models of Huntington's disease, changes in P2X receptor-mediated neurotransmission in cortico-striatal projections were observed (DiezZaera et al., 2007). Both P2X4 and P2X7 receptors have been implicated in the transgenic superoxide dismutase 1 (SOD1) mouse model of ALS (Andries et al., 2007; Apolloni et al., 2013). In MS lesions in brain tissue, P2X7 receptors were detected on reactive astrocytes (Narcisse et al., 2005). Lesional accumulation of P2X receptors on macrophages in the CNS of the rat model of MS, experimental autoimmune encephalomyelitis, has been reported (Guo and Schluesener, 2005). P2X7 expression is elevated in astrocytes in MS patients (Narcisse et al., 2005).

$\mathrm{P} 2 \mathrm{X} 7$ receptors on microglia, the immune cells in the CNS, are activated by purines to release inflammatory cytokines such as IL-1 $\beta$, IL-6, and tumor necrosis factor- $\alpha$ (Di Virgilio, 2007). P2X7 receptors have been implicated in the formation of multinucleated giant macrophage-derived cells, a feature of chronic inflammatory reactions (Lemaire et al., 2006). Prion infection has been claimed to be associated with hypersensitivity of $\mathrm{P} 2 \mathrm{X} 7$ receptors in microglia (Takenouchi et al., 2007). Microglial cell activation by pro-inflammatory bacterial lipopolysaccharide leads to a transient increase in ivermectin-sensitive P2X4 receptor currents (Raouf et al., 2007). Activation of astrocytes via P2X7 receptors increases chemokine monocyte chemoattractant protein-1 expression and it was suggested that this may be important for communication with haematopoietic inflammatory cells (Panenka et al., 2001).

Generalized motor seizures can be evoked by microinjection of ATP analogs into the prepiriform cortex (Knutsen and Murray, 1997). The prepiriform cortex expresses P2X2, P2X4, and $\mathrm{P} 2 \mathrm{X} 6$ receptors and it was suggested that $\mathrm{P} 2 \mathrm{X}$ receptor antagonists may have potential as neuroleptic agents. In chronic epileptic rats, the hippocampus showed abnormal responses to ATP, associated with increased expression of $\mathrm{P} 2 \mathrm{X} 7$ receptors, which were upregulated in rats with chronic pilocarpineinduced epilepsy and may be involved in the pathophysiology of temporal lobe epilepsy. Enhanced immunoreactivity of the $\mathrm{P} 2 \mathrm{X} 7$ receptor was observed in microglia from rat brain following kainate-provoked seizures (Rappold et al., 2006). A decrease of presynaptic P2X receptors in the hippocampus of rats that have suffered a convulsive period has been shown (Oses, 2006). Glutamate release from astrocytes induced by ATP has been described in epileptogenesis (Tian et al., 2005).

The $\mathrm{P} 2 \mathrm{X} 7$ receptor gene has been implicated in both major depressive illness (Lucae et al., 2006) and bipolar affective disorders (Barden et al., 2006). In schizophrenia, the involvement of ATP receptors has been implicated in relation to reports that the antipsychotic drugs haloperidol, chlorpromazine and fluspirilene, inhibit ATP-evoked responses mediated by P2X receptors (Inoue et al., 1996). It has been suggested that ATP may have a facilitating role for dopaminergic transmission and that some antipsychotic drugs express their therapeutic effects by suppression of dopaminergic hyperactivity through inhibition of P2X receptor-mediated effects. Ethanol is probably the oldest and most widely used psychoactive drug. The cellular mechanisms underlying its actions are not well-understood, but some insights in relation to purinergic P2 receptor signaling have emerged in recent years (Davies et al., 2005). P2X receptor-mediated responses of DRG neurons are inhibited by ethanol by an allosteric mechanism. For P2X4 receptors, ethanol inhibition is altered by mutation of histidine 241. Ethanol differentially affects ATPgated $\mathrm{P} 2 \mathrm{X} 3$ and $\mathrm{P} 2 \mathrm{X} 4$ receptor subtypes expressed by Xenopus oocytes.

Table 2 | Agonists and antagonists for the different P2X receptor subtypes.

\begin{tabular}{|c|c|c|}
\hline $\begin{array}{l}\text { Receptor } \\
\text { Subtype }\end{array}$ & Agonists & Antagonists \\
\hline $\mathrm{P} 2 \mathrm{X} 1$ & $\begin{array}{l}\text { BzATP }>\text { ATP }=2-M e S A T P=\alpha, \beta-\text { meATP }= \\
\text { L- } \beta, \gamma \text {-meATP (rapid desensitization); PAPET-ATP }\end{array}$ & NF449 > IP $5 \mid>$ TNP-ATP $>$ RO $0437626>$ NF279, NF023, RO1, MRS2159 \\
\hline $\mathrm{P} 2 \mathrm{X} 2$ & $\begin{array}{l}\text { ATP } \geq \text { ATP } \gamma S \geq 2-M e S A T P>>\alpha, \beta-\text { meATP }(p H+\text { zinc } \\
\text { sensitive); } \beta, \gamma-\text { CF }_{2} \text { ATP }\end{array}$ & $\begin{array}{l}\text { PSB-1011 > RB2, isoPPADS > PPADS > Suramin, NF770, NF778, } \\
\text { Aminoglycoside }\end{array}$ \\
\hline $\mathrm{P} 2 \mathrm{X} 4$ & $\begin{array}{l}\text { ATP }>>\alpha, \beta-\text { meATP }>>\text { CTP, 2-MeSATP Ivermectin } \\
\text { potentiation }\end{array}$ & $\begin{array}{l}\text { 5-BDBD >> TNP-ATP, PPADS > BBG, Paroxetine, phenolphthalein, CO donor } \\
\text { (CORM 2) }\end{array}$ \\
\hline $\mathrm{P} 2 \times 5$ & 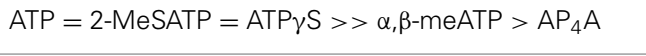 & BBG $>$ PPADS, Suramin \\
\hline
\end{tabular}




\section{PAIN}

There are reviews that have addressed this topic (see, for example, Burnstock, 2009c,d; Jarvis, 2010; Tsuda et al., 2010; Trang et al., 2012). Visceral pain is a common form of pain associated with pathological conditions such as renal colic, dyspepsia, inflammatory bowel disease, angina, dysmenorrhoea, and interstitial cystitis. P2X3 (homomultimer) and P2X2/3 (heteromultimer) receptors have been cloned and shown to be mainly located on small nociceptive sensory neurons in the DRG (Lewis et al., 1995).

It was proposed in 1999 that purinergic mechanosensory transduction occurred in visceral tubes and sacs, including ureter, bladder and gut, where ATP released from lining epithelial cells during distension acted on $\mathrm{P} 2 \mathrm{X} 3$ and $\mathrm{P} 2 \mathrm{X} 2 / 3$ receptors on subepithelial nociceptive sensory nerves to initiate impulses in sensory pathways to pain centers in the CNS (Burnstock, 1999) (Figure 2). P2X3 receptor knockout mice exhibited reduced inflammatory pain and marked urinary bladder hyporeflexia with reduced voiding frequency, suggesting that P2X3 receptors were involved in mechanosensory transduction underlying both inflammatory pain and physiological voiding reflexes (Cockayne et al., 2000). ATP was shown to be released from bladder urothelial cells during distension, and activity initiated in pelvic sensory nerves was mimicked by ATP and $\alpha, \beta$-methylene ATP $(\alpha, \beta$-meATP) and attenuated by P2X3 antagonists as well as in P2X3 knockout mice (Vlaskovska et al., 2001). Passage of a kidney stone through the ureter causes severe pain. P2X3 receptor immunostaining of sensory nerves in the suburothelial region was reported (Lee et al., 2000). Using a guinea-pig preparation, perfused in vitro, multifiber recordings of ureter afferent nerve activity were made (Rong and Burnstock, 2004). Distension of the guinea-pig ureter resulted in increased spike discharge in sensory nerves, which was mimicked by ATP and reduced by $\mathrm{P} 2 \mathrm{X} 3$ receptor antagonists. Pressure-dependent release of ATP from urothelial cells to about 10 times the basal release levels resulted from distension of both the perfused guineapig and human ureters (Knight et al., 2002; Calvert et al., 2008).

Purinergic mechanosensory transduction in the gut initiated both physiological reflex modulation of peristalsis via intrinsic sensory fibers and nociception via extrinsic sensory fibers (Burnstock, 2001b). Distension of a pelvic sensory nervecolorectal preparation led to pressure-dependent increase in release of ATP from mucosal epithelial cells and evoked pelvic nerve excitation. This excitation was mimicked by application of ATP and $\alpha, \beta$-meATP and attenuated by selective P2X3 and P2X2/3 antagonists (Wynn et al., 2003).

$\mathrm{P} 2 \mathrm{X} 3$ and $\mathrm{P} 2 \mathrm{X} 2 / 3$ receptors located on primary afferent nerve terminals in inner lamina 2 of the spinal cord, also play a significant role in neuropathic and inflammatory pain (see Wirkner et al., 2007; Burnstock, 2009a). Dorsal horn neurons relaying nociceptive information further along the pain pathway express P2X2, P2X4, and P2X6 receptors (Bardoni et al., 1997). Microglial $\mathrm{P} 2 \mathrm{X} 4$ and $\mathrm{P} 2 \mathrm{X} 7$ receptors are also involved in neuropathic pain (Tsuda et al., 2003; Hughes et al., 2007), although the underlying mechanisms are still under investigation (Inoue, 2007; Trang and Salter, 2012). Neuropathic pain and allodynia are abolished in both P2X4 and P2X7 knockout mice, so there is much interest in finding selective antagonists that are suitable for therapeutic development (see McGaraughty et al., 2007).

ATP involvement in migraine was first suspected in relation to the vascular theory of this disorder with ATP released from endothelial cells in microvessels during reactive hyperaemia, which is associated with pain, following cerebral vascular vasospasm (that is not associated with pain; Burnstock, 1989). $\mathrm{P} 2 \mathrm{X} 3$ receptor involvement in neuronal dysfunction in brain areas that mediate nociception in migraine, such as the trigeminal nucleus and thalamus, has also been proposed (Fabbretti et al., 2006), and may represent a novel target for antimigraine drugs (Fumagalli et al., 2006). Anti-nerve growth factor treatment suppressed responses evoked by $\mathrm{P} 2 \mathrm{X} 3$ receptor activation in an in vivo model of mouse trigeminal pain (D'Arco et al., 2007).

\section{P2X RECEPTOR AGONISTS AND ANTAGONISTS—THERAPEUTIC POTENTIAL}

$\mathrm{P} 2 \mathrm{X}$ receptors consist of a family of ligand-gated cation channels that are widely expressed in nerves and many non-neuronal cells. Table 2 summarizes the selective agonists and antagonists currently available for the $\mathrm{P} 2 \mathrm{X}$ receptor subtypes. With the recent discovery of their crystal structure (Kawate et al., 2009), medicinal chemists now have a detailed understanding of how the individual subunits that form the receptor interact with each other and are in a better position to prepare selective $\mathrm{P} 2 \mathrm{X}$ receptor agonists and antagonists. P2X receptors change expression in pathological conditions, suggesting that they may be useful targets for treatment of diseases. The clinical manipulation of purinergic signaling is in its infancy. One of the main reasons why we do not yet have more purinergic therapeutic drugs is the scarcity of receptor-subtype-selective agonists and antagonists that can be used in vivo. Afferent Pharmaceuticals have recently developed some small molecules (AF-353 and derivatives) as P2X3 and $\mathrm{P} 2 \mathrm{X} 2 / 3$ antagonists that are orally bioavailable and stable in vivo and which are currently in clinical trial (Gever et al., 2006, 2010). There has also been promising development of clinically relevant P2X7 antagonists recently, notably the Abbott compounds A438079 and A-317491 (McGaraughty et al., 2007). However, antagonists for some of the other P2X subtypes are still to be developed. Therapeutic strategies in the future are also likely to include agents that control the expression of $\mathrm{P} 2$ receptors, inhibitors of extracellular breakdown of ATP and enhancers and inhibitors of ATP transport.

\section{TOPICS COVERED IN THIS SPECIAL ISSUE}

Included in this Special Issue are papers by Elsa Fabbretti, Rashid Giniatullin and Anthony Ford about P2X3 receptors; Stanko Stojilkovic, Terrance Egan, Ruth Murell-Lagnado, Annette Nicke, Thomas Grutter and Philippe Seguela about the molecular physiology and targeting of P2X receptors; Sam Fountain about the evolution of P2X receptors; Manfred Frick and Kazu Inoue about P2X4 receptors involved in lung surfactant secretion and microglia-mediated neuropathic pain; David Henshall about $\mathrm{P} 2 \mathrm{X}$ receptors as therapeutic targets for epilepsy; Gary Housley and Sue Kinnamon about P2X receptors in hearing and taste; and Antony Triller about P2X7 receptors. 


\section{REFERENCES}

Abbracchio, M. P., and Burnstock, G. (1994). Purinoceptors: are there families of $\mathrm{P}_{2 \mathrm{X}}$ and $\mathrm{P}_{2 \mathrm{Y}}$ purinoceptors? Pharmacol. Ther. 64, 445-475. doi: 10.1016/01637258(94)00048-4

Abraham, E. H., Salikhova, A. Y., and Rapaport, E. (2003). ATP in the treatment of advanced cancer. Curr. Topics Membr. 54, 415-452. doi: 10.1016/S10635823(03)01013-5

Adinolfi, E., Melchiorri, L., Falzoni, S., Chiozzi, P., Morelli, A., Tieghi, A., et al. (2002). P2X7 receptor expression in evolutive and indolent forms of chronic B lymphocytic leukemia. Blood 99, 706-708. doi: 10.1182/blood.V99.2.706

Adriaensen, D., and Timmermans, J. P. (2004). Purinergic signalling in the lung: important in asthma and COPD? Curr. Opin. Pharmacol. 4, 207-214. doi: 10.1016/j.coph.2004.01.010

Agboh, K. C., Webb, T. E., Evans, R. J., and Ennion, S. J. (2004). Functional characterization of a P2X receptor from Schistosoma mansoni. J. Biol. Chem. 279, 41650-41657. doi: 10.1074/jbc.M408203200

Agteresch, H. J., van Rooijen, M. H. C., van den Berg, J. W. O., MindermanVoortman, G. J., Wilson, J. H. P., and Dagnelie, P. C. (2003). Growth inhibition of lung cancer cells by adenosine 5-triphosphate. Drug Dev. Res. 60, 196-203. doi: $10.1002 /$ ddr.10296

Andries, M., Van Damme, P., Robberecht, W., and Van Den Bosch, L. (2007). Ivermectin inhibits AMPA receptor-mediated excitotoxicity in cultured motor neurons and extends the life span of a transgenic mouse model of amyotrophic lateral sclerosis. Neurobiol. Dis. 25, 8-16. doi: 10.1016/j.nbd.2006.08.018

Antunes, V. R., Bonagamba, L. G., and Machado, B. H. (2005). Hemodynamic and respiratory responses to microinjection of ATP into the intermediate and caudal NTS of awake rats. Brain Res. 1032, 85-93. doi: 10.1016/j.brainres.2004.10.048

Apolloni, S., Amadio, S., Montilli, C., Volonté, C., and D'Ambrosi, N. (2013). Ablation of P2X7 receptor exacerbates gliosis and motoneuron death in the SOD1-G93A mouse model of amyotrophic lateral sclerosis. Hum. Mol. Genet. 22, 4102-4116. doi: 10.1093/hmg/ddt259

Bailey, M. A., and Shirley, D. G. (2009). Effects of extracellular nucleotides on renal tubular solute transport. Purinergic Signal. 5, 473-480. doi: 10.1007/s11302009-9149-z

Barden, N., Harvey, M., Gagné, B., Shink, E., Tremblay, M., Raymond, C., et al. (2006). Analysis of single nucleotide polymorphisms in genes in the chromosome 12Q24.31 region points to P2RX7 as a susceptibility gene to bipolar affective disorder. Am. J. Med. Genet. B Neuropsychiatr. Genet. 141, 374-382. doi: 10.1002/ajmg.b.30303

Bardoni, R., Goldstein, P. A., Lee, C. J., Gu, J. G., and MacDermott, A. B. (1997) ATP $\mathrm{P}_{2 \mathrm{X}}$ receptors mediate fast synaptic transmission in the dorsal horn of the rat spinal cord. J. Neurosci. 17, 5297-5304.

Baroni, M., Pizzirani, C., Pinotti, M., Ferrari, D., Adinolfi, E., Calzavarini, S., et al. (2007). Stimulation of $\mathrm{P} 2\left(\mathrm{P}_{2} \mathrm{X}_{7}\right)$ receptors in human dendritic cells induces the release of tissue factor-bearing microparticles. FASEB J. 21, 1926-1933. doi: 10.1096/fj.06-7238com

Bian, X., Ren, J., DeVries, M., Schnegelsberg, B., Cockayne, D. A., Ford, A. P., et al. (2003). Peristalsis is impaired in the small intestine of mice lacking the $\mathrm{P}_{2} \mathrm{X}_{3}$ subunit. J. Physiol. 551, 309-322. doi: 10.1113/jphysiol.2003.044172

Bo, X., Alavi, A., Xiang, Z., Oglesby, I., Ford, A., and Burnstock, G. (1999). Localization of ATP-gated $\mathrm{P} 2 \mathrm{X}_{2}$ and $\mathrm{P} 2 \mathrm{X}_{3}$ receptor immunoreactive nerves in rat taste buds. Neuroreport 10, 1107-1111. doi: 10.1097/00001756-19990406000037

Bodin, P., and Burnstock, G. (2001). Purinergic signalling: ATP release. Neurochem. Res. 26, 959-969. doi: 10.1023/A:1012388618693

Boselli, C., Govoni, S., Condino, A. M., and D'Agostino, G. (2001). Bladder instability: a re-appraisal of classical experimental approaches and development of new therapeutic strategies. J. Auton. Pharmacol. 21, 219-229. doi: 10.1046/j.1365-2680.2001.00235.x

Brake, A. J., Wagenbach, M. J., and Julius, D. (1994). New structural motif for ligand-gated ion channels defined by an ionotropic ATP receptor. Nature 371, 519-523. doi: 10.1038/371519a0

Bulanova, E., Budagian, V., Orinska, Z., Koch-Nolte, F., Haag, F., and Bulfone-Paus, S. (2009). ATP induces $\mathrm{P}_{2} \mathrm{X}_{7}$ receptor-independent cytokine and chemokine expression through $\mathrm{P}_{2} \mathrm{X}_{1}$ and $\mathrm{P}_{2} \mathrm{X}_{3}$ receptors in murine mast cells. J. Leukoc. Biol. 85, 692-702. doi: 10.1189/jlb.0808470

Burnstock, G. (1978). "A basis for distinguishing two types of purinergic receptor," in Cell Membrane Receptors for Drugs and Hormones: A Multidisciplinary Approach, eds R. W. Straub and L. Bolis (New York, NY: Raven Press), 107-118.
Burnstock, G. (1989). The role of adenosine triphosphate in migraine. Biomed. Pharmacother. 43, 727-736. doi: 10.1016/0753-3322(89)90161-3

Burnstock, G. (1990). Noradrenaline and ATP as cotransmitters in sympathetic nerves. Neurochem. Int. 17, 357-368. doi: 10.1016/0197-0186(90)90158-P

Burnstock, G. (1999). Release of vasoactive substances from endothelial cells by shear stress and purinergic mechanosensory transduction. J. Anat. 194, 335-342. doi: 10.1046/j.1469-7580.1999.19430335.x

Burnstock, G. (2001a). "Purinergic signalling in lower urinary tract," in Handbook of Experimental Pharmacology, Vol. 151/I. Purinergic and Pyrimidinergic Signalling I - Molecular, Nervous and Urinogenitary System Function, eds M. P. Abbracchio and M. Williams (Berlin: Springer-Verlag), 423-515.

Burnstock, G. (2001b). Purine-mediated signalling in pain and visceral perception. Trends Pharmacol. Sci. 22, 182-188. doi: 10.1016/S0165-6147(00)01643-6

Burnstock, G. (2006a). Purinergic P2 receptors as targets for novel analgesics. Pharmacol. Therap. 110, 433-454. doi: 10.1016/j.pharmthera.2005.08.013

Burnstock, G. (2006b). Pathophysiology and therapeutic potential of purinergic signaling. Pharmacol. Rev. 58, 58-86. doi: 10.1124/pr.58.1.5

Burnstock, G. (2007a). Purine and pyrimidine receptors. Cell. Mol. Life Sci. 64, 1471-1483. doi: 10.1007/s00018-007-6497-0

Burnstock, G. (2007b). Physiology and pathophysiology of purinergic neurotransmission. Physiol. Rev. 87, 659-797. doi: 10.1152/physrev.00043.2006

Burnstock, G. (2008a). Purinergic signalling and disorders of the central nervous system. Nature Revs. Drug Discovery 7, 575-590. doi: 10.1038/nrd2605

Burnstock, G. (2008b). The journey to establish purinergic signalling in the gut. Neurogastroenterol. Motil. 20, 8-19. doi: 10.1111/j.1365-2982.2008.01107.x

Burnstock, G. (2008c). Commentary. Purinergic receptors as future targets for treatment of functional GI disorders. Gut 57, 1193-1194. doi: 10.1136/gut.2008. 151134

Burnstock, G. (2009a). Purines and sensory nerves. Hndbk. Exp. Pharmacol. 194, 333-392. doi: 10.1007/978-3-540-79090-7_10

Burnstock, G. (2009b). Purinergic cotransmission. Exp. Physiol. 94, 20-24. doi: 10.1113/expphysiol.2008.043620

Burnstock, G. (2009c). Purinergic mechanosensory transduction and visceral pain. Mol. Pain 5, 69. doi: 10.1186/1744-8069-5-69

Burnstock, G. (2009d). Purinergic receptors and pain. Curr. Pharm. Des. 15, 1717-1735. doi: 10.2174/138161209788186335

Burnstock, G. (2012). P2X receptors in the gut. WIREs Membrane Transport and Signaling 1, 269-279. doi: 10.1002/wmts.16

Burnstock, G. (2013). Purinergic signalling in the lower urinary tract. Acta Physiologica 207, 40-52. doi: 10.1111/apha.12012

Burnstock, G., and Arnett, T. R. (2006). Edited Monograph: Nucleotides and Regulation of Bone Cell Function. Boca Raton, FL: Taylor \& Francis Group.

Burnstock, G., Arnett, T. R., and Orriss, I. R. (2013). Purinergic signalling in the musculoskeletal system. Purinergic Signal. doi: 10.1007/s11302-013-9381-4. [Epub ahead of print].

Burnstock, G., Brouns, I., Adriaensen, D., and Timmermans, J. P. (2012a). Purinergic signalling in the airways. Pharmacol. Rev. 64, 834-868. doi: 10.1124/pr.111.005389

Burnstock, G., Knight, G. E., and Greig, A. V. H. (2012b). Purinergic signalling in healthy and diseased skin. J. Invest. Dermatol. 132, 526-546. doi: 10.1038/jid.2011.344

Burnstock, G., Cocks, T., Crowe, R., and Kasakov, L. (1978). Purinergic innervation of the guinea-pig urinary bladder. Br. J. Pharmacol. 63, 125-138. doi: 10.1111/j.1476-5381.1978.tb07782.x

Burnstock, G., and Di Virgilio, F. (2013). Purinergic signalling in cancer. Purinergic Signal. doi: 10.1007/s11302-013-9372-5. [Epub ahead of print].

Burnstock, G., and Kennedy, C. (1985). Is there a basis for distinguishing two types of P2-purinoceptor? Gen. Pharmacol. 16, 433-440. doi: 10.1016/03063623(85)90001-1

Burnstock, G., and Knight, G. E. (2004). Cellular distribution and functions of P2 receptor subtypes in different systems. Int. Rev. Cytol. 240, 31-304. doi: 10.1016/S0074-7696(04)40002-3

Burnstock, G., Krügel, U., Abbracchio, M. P., and Illes, P. (2011a). Purinergic signalling: from normal behaviour to pathological brain function. Prog. Neurobiol. 95, 229-274. doi: 10.1016/j.pneurobio.2011.08.006

Burnstock, G., Verkhratsky, A., and Fredholm, B. (2011b). Adenosine and ATP receptors in the brain. Curr. Top. Med. Chem. 11, 973-1011. doi: $10.2174 / 156802611795347627$ 
Burnstock, G., and Novak, I. (2013). Purinergic signalling and diabetes. Purinergic Signal. 9, 307-324. doi: 10.1007/s11302-013-9359-2

Burnstock, G., and Verkhratsky, A. (2012a). Evolution of P2X receptors. WIREs Membrane Transport and Signaling 1, 188-200. doi: 10.1002/wmts.13

Burnstock, G., and Verkhratsky, A. (2012b). Purinergic Signalling and the Nervous System. Heidelberg; Berlin: Springer. doi: 10.1007/978-3-642-28863-0

Calvert, R. C., Shabbir, M., Thompson, C. S., Mikhailidis, D. P., Morgan, R., and Burnstock, G. (2004). Immunocytochemical and pharmacological characterisation of P2-purinoceptor-mediated cell growth and death in PC-3 hormone refractory prostate cancer cells. Anticancer Res. 24, 2853-2859.

Calvert, R. C., Thompson, C. S., and Burnstock, G. (2008). ATP release from the human ureter on distension and $\mathrm{P}_{2} \mathrm{X}_{3}$ receptor expression on suburothelial sensory nerves. Purinergic Signal. 4, 377-381. doi: 10.1007/s11302-008-9123-1

Cavaliere, F., Florenzano, F., Amadio, S., Fusco, F. R., Viscomi, M. T., D’Ambrosi, N., et al. (2003). Up-regulation of $\mathrm{P} 2 \mathrm{X}_{2}, \mathrm{P} 2 \mathrm{X}_{4}$ receptor and ischemic cell death: prevention by P2 antagonists. Neuroscience 120, 85-98. doi: 10.1016/S03064522(03)00228-8

Chen, C. C., Akopian, A. N., Sivilotti, L., Colquhoun, D., Burnstock, G., and Wood, J. N. (1995). A P2X purinoceptor expressed by a subset of sensory neurons. Nature 377, 428-431. doi: 10.1038/377428a0

Chess-Williams, R. (2004). Potential therapeutic targets for the treatment of detrusor overactivity. Expert. Opin. Ther. Targets. 8, 95-106. doi: 10.1517/14728222.8.2.95

Cockayne, D. A., Hamilton, S. G., Zhu, Q.-M., Dunn, P. M., Zhong, Y., Novakovic, S., et al. (2000). Urinary bladder hyporeflexia and reduced pain-related behaviour in P2X3-deficient mice. Nature 407, 1011-1015. doi: $10.1038 / 35039519$

Collo, G., North, R. A., Kawashima, E., Merlo-Pich, E., Neidhart, S., Surprenant, A., et al. (1996). Cloning of $\mathrm{P}_{2} \mathrm{X}_{5}$ and $\mathrm{P}_{2} \mathrm{X}_{6}$ receptors and the distribution and properties of an extended family of ATP-gated ion channels. J. Neurosci. 16, 2495-2507.

Coutinho-Silva, R., Parsons, M., Robson, T., and Burnstock, G. (2001). Changes in expression of $\mathrm{P} 2$ receptors in rat and mouse pancreas during development and aging. Cell Tissue Res. 306, 373-383. doi: 10.1007/s004410100458

Coutinho-Silva, R., Parsons, M., Robson, T., Lincoln, J., and Burnstock, G. (2003). $\mathrm{P} 2 \mathrm{X}$ and $\mathrm{P} 2 \mathrm{Y}$ purinoceptor expression in pancreas from streptozotocin-diabetic rats. Mol. Cell. Endocrinol. 204, 141-154. doi: 10.1016/S0303-7207(03)00003-0

Dang, K., Bielfeldt, K., Lamb, K., and Gebhart, G. F. (2005). Gastric ulcers evoke hyperexcitability and enhance P2X receptor function in rat gastric sensory neurons. J. Neurophysiol. 93, 3112-3119. doi: 10.1152/jn.01127.2004

D’Arco, M., Giniatullin, R., Simonetti, M., Fabbro, A., Nair, A., Nistri, A., et al. (2007). Neutralization of nerve growth factor induces plasticity of ATP-sensitive $\mathrm{P}_{2} \mathrm{X}_{3}$ receptors of nociceptive trigeminal ganglion neurons. J. Neurosci. 27, 8190-8201. doi: 10.1523/JNEUROSCI.0713-07.2007

Davies, D. L., Kochegarov, A. A., Kuo, S. T., Kulkarni, A. A., Woodward, J. J., King, B. F., et al. (2005). Ethanol differentially affects ATP-gated $\mathrm{P}_{2} \mathrm{X}_{3}$ and $\mathrm{P} 2 \mathrm{X}_{4}$ receptor subtypes expressed in Xenopus oocytes. Neuropharmacology 49, 243-253. doi: 10.1016/j.neuropharm.2005.03.015

Dell'Antonio, G., Quattrini, A., Cin, E. D., Fulgenzi, A., and Ferrero, M. E. (2002). Relief of inflammatory pain in rats by local use of the selective $\mathrm{P}_{2} \mathrm{X}_{7}$ ATP receptor inhibitor, oxidized ATP. Arthritis Rheum. 46, 3378-3385. doi: 10.1002/art.10678

Denda, M., Inoue, K., Fuziwara, S., and Denda, S. (2002). P2X purinergic receptor antagonist accelerates skin barrier repair and prevents epidermal hyperplasia induced by skin barrier disruption. J. Invest. Dermatol. 119, 1034-1040. doi: 10.1046/j.1523-1747.2002.19505.x

Di Virgilio, F. (2007). Liaisons dangereuses: $\mathrm{P} 2 \mathrm{X}_{7}$ and the inflammasome. Trends Pharmacol. Sci. 28, 465-472. doi: 10.1016/j.tips.2007.07.002

Di Virgilio, F. (2013). The therapeutic potential of modifying inflammasomes and NOD-like receptors. Pharmacol Rev 65, 872-905. doi: 10.1124/pr.112.006171

Di Virgilio, F., Ferrari, D., and Adinolfi, E. (2009). P2X 7 : a growthpromoting receptor-implications for cancer. Purinergic Signal. 5, 251-256. doi: 10.1007/s11302-009-9145-3

Diez-Zaera, M., Diaz-Hernandez, M., Alberch, J., Miras-Portugal, M. T., and Lucas, J. J. (2007). Purinergic system in Huntington's disease: develop of new therapeutic strategies. J. Neurochem. 101, 66.

Duarte, J. M., Oses, J. P., Rodrigues, R. J., and Cunha, R. A. (2007). Modification of purinergic signaling in the hippocampus of streptozotocin-induced diabetic rats. Neuroscience 149, 382-391. doi: 10.1016/j.neuroscience.2007.08.005
Dunn, P. M. (2000). Fertility: purinergic receptors and the male contraceptive pill. Curr. Biol. 10, R305-R307. doi: 10.1016/S0960-9822(00)00436-X

Edwards, F. A., Gibb, A. J., and Colquhoun, D. (1992). ATP receptor-mediated synaptic currents in the central nervous system. Nature 359, 144-147. doi: 10.1038/359144a0

Evans, R. J., Derkach, V., and Surprenant, A. (1992). ATP mediates fast synaptic transmission in mammalian neurons. Nature 357, 503-505. doi: $10.1038 / 357503 \mathrm{a} 0$

Fabbretti, E., D’Arco, M., Fabbro, A., Simonetti, M., Nistri, A., and Giniatullin, R. (2006). Delayed upregulation of ATP P2X $\mathrm{X}_{3}$ receptors of trigeminal sensory neurons by calcitonin gene-related peptide. J. Neurosci. 26, 6163-6171. doi: 10.1523/JNEUROSCI.0647-06.2006

Facer, P., Knowles, C. H., Tam, P. K., Ford, A. P., Dyer, N., Baecker, P. A., et al. (2001). Novel capsaicin (VR1) and purinergic (P2X3) receptors in Hirschsprung's intestine. J. Pediatr. Surg. 36, 1679-1684. doi: 10.1053/jpsu.2001.27959

Ferrari, D., Munerati, M., Melchiorri, L., Hanau, S., Di Virgilio, F., and Baricordi, O. R. (1994). Responses to extracellular ATP of lymphoblastoid cell lines from Duchenne muscular dystrophy patients. Am. J. Physiol. 267, C886-C892.

Fountain, S. J., and Burnstock, G. (2009). An evolutionary history of P2X receptors. Purinergic Signal. 5, 269-272. doi: 10.1007/s11302-008-9127-x

Franke, H., Krügel, U., and Illes, P. (2006). P2 receptors and neuronal injury. Pflugers Arch. 452, 622-644. doi: 10.1007/s00424-006-0071-8

Franke, H., Verkhratsky, A., Burnstock, G., and Illes, P. (2012). Pathophysiology of astroglial purinergic signalling. Purinergic Signal. 8, 629-657. doi: 10.1007/s11302-012-9300-0

Fumagalli, M., Ceruti, S., Verderio, C., and Abbracchio, M. P. (2006). ATP as a neurotransmitter of pain in migraine: a functional role for $\mathrm{P} 2 \mathrm{Y}$ receptors in primary cultures from mouse trigeminal sensory ganglia. Purinergic Signal. 2, 120-121.

Galligan, J. J. (2004). Enteric P2X receptors as potential targets for drug treatment of the irritable bowel syndrome. Br. J. Pharmacol. 141, 1294-1302. doi: 10.1038/sj.bjp.0705761

Gayle, S., and Burnstock, G. (2005). Immunolocalisation of P2X and P2Y nucleotide receptors in the rat nasal mucosa. Cell Tiss. Res. 319, 27-36. doi: 10.1007/s00441-004-0979-2

Gever, J., Cockayne, D. A., Dillon, M. P., Burnstock, G., and Ford, A. P. D. W. (2006). Pharmacology of P2X channels. Pflugers Arch. 452, 513-537. doi: 10.1007/s00424-006-0070-9

Gever, J. R., Rothschild, S., Henningsen, R., Martin, R., Hackos, D., Panicker, S., et al. (2010). AF-353, a novel, potent orally bioavailable $\mathrm{P} 2 \mathrm{X} 3 / \mathrm{P} 2 \mathrm{X} 2 / 3$ receptor antagonist. Br. J. Pharmacol. 160, 1387-1398. doi: 10.1111/j.14765381.2010.00796.x

Glass, R., Bardini, M., Robson, T., and Burnstock, G. (2001). Expression of nucleotide $\mathrm{P} 2 \mathrm{X}$ receptor subtypes during spermatogenesis in the adult rat testis. Cells Tiss. Org. 169, 377-387. doi: 10.1159/000047905

Gonzales, E. B., Kawate, T., and Gouaux, E. (2009). Pore architecture and ion sites in acid-sensing ion channels and P2X receptors. Nature 460, 599-604. doi: 10.1038/nature08218

Gorodeski, G. I. (2002). Regulation of transcervical permeability by two distinct P2 purinergic receptor mechanisms. Am. J. Physiol. Cell Physiol. 282, C75-C83.

Gourine, A. V., Atkinson, L., Deuchars, J., and Spyer, K. M. (2003). Purinergic signalling in the medullary mechanisms of respiratory control in the rat: respiratory neurones express the $\mathrm{P}_{2} \mathrm{X}_{2}$ receptor subunit. J. Physiol. 552, 197-211. doi: 10.1113/jphysiol.2003.045294

Greig, A. V. H., James, S. E., McGrouther, D. A., Terenghi, G., and Burnstock, G. (2003a). Purinergic receptor expression in the regenerating epidermis in a rat model of normal and delayed wound healing. Exp. Dermatol. 12, 860-871. doi: 10.1111/j.0906-6705.2003.00110.x

Greig, A. V. H., Linge, C., Healy, V., Lim, P., Clayton, E., Rustin, M. H., et al. (2003b). Expression of purinergic receptors in non-melanoma skin cancers and their functional roles in A431 cells. J. Invest. Dermatol. 121, 315-327. doi: 10.1046/j.1523-1747.2003.12379.x

Greig, A. V. H., Linge, C., Terenghi, G., McGrouther, D. A., and Burnstock, G. (2003c). Purinergic receptors are part of a functional signalling system for proliferation and differentiation of human epidermal keratinocytes. J. Invest. Dermatol. 120, 1007-1015. doi: 10.1046/j.1523-1747.2003.12261.x

Gu, J. G., and MacDermott, A. B. (1997). Activation of ATP P2X receptors elicits glutamate release from sensory neuron synapses. Nature 389, 749-753. doi: $10.1038 / 39639$ 
Guo, L. H., and Schluesener, H. J. (2005). Lesional accumulation of P2X $\mathrm{X}_{4}$ receptor ${ }^{+}$ macrophages in rat CNS during experimental autoimmune encephalomyelitis. Neuroscience 134, 199-205. doi: 10.1016/j.neuroscience.2005.04.026

Hamilton, S. G., McMahon, S. B., and Lewin, G. R. (2001). Selective activation of nociceptors by $\mathrm{P} 2 \mathrm{X}$ receptor agonists in normal and inflamed rat skin. J. Physiol. 534, 437-445. doi: 10.1111/j.1469-7793.2001.00437.x

Hansen, M. A., Dutton, J. L., Balcar, V. J., Barden, J. A., and Bennett, M. R. (1999). $\mathrm{P}_{2 \mathrm{X}}$ (purinergic) receptor distributions in rat blood vessels. J. Auton. Nerv. Syst. 75, 147-155. doi: 10.1016/S0165-1838(98)00189-1

Hegg, C. C., and Lucero, M. T. (2006). Purinergic receptor antagonists inhibit odorant-induced heat shock protein 25 induction in mouse olfactory epithelium. Glia 53, 182-190. doi: 10.1002/glia.20258

Henning, R. H. (1997). Purinoceptors in neuromuscular transmission. Pharmacol. Ther. 74, 115-128. doi: 10.1016/S0163-7258(97)00015-6

Hoebertz, A., Arnett, T. R., and Burnstock, G. (2003). Regulation of bone resorption and formation by purines and pyrimidines. Trends Pharmacol. Sci. 24 290-297. doi: 10.1016/S0165-6147(03)00123-8

Housley, G., and Gale, J. (Guest Editors). (2010). Special Issue: Purinergic signalling in the inner ear. Purinergic signal. 6, 149-287. doi: 10.1007/s11302-010-9196-5

Housley, G. D. (2000). Physiological effects of extracellular nucleotides in the inner ear. Clin. Exp. Pharmacol. Physiol. 27, 575-580. doi: 10.1046/j.14401681.2000.03314.x

Housley, G. D., Bringmann, A., and Reichenbach, A. (2009). Purinergic signaling in special senses. Trends Neurosci. 32, 128-141. doi: 10.1016/j.tins.2009. 01.001

Hughes, J. P., Hatcher, J. P., and Chessell, I. P. (2007). The role of $\mathrm{P}_{2} \mathrm{X}_{7}$ in pain and inflammation. Purinergic Signal. 3, 163-169. doi: 10.1007/s11302-006-9031-1

Inoue, K. (2007). P2 receptors and chronic pain. Purinergic Signal. 3, 135-144. doi: $10.1007 / \mathrm{s} 11302-006-9045-8$

Inoue, K., Koizumi, S., and Ueno, S. (1996). Implication of ATP receptors in brain functions. Prog. Neurobiol. 50, 483-492. doi: 10.1016/S0301-0082(96)00037-8

Jarvis, M. F. (2010). The neural-glial purinergic receptor ensemble in chronic pain states. Trends Neurosci. 33, 48-57. doi: 10.1016/j.tins.2009.10.003

Kälvegren, H., Skoglund, C., Helldahl, C., Lerm, M., Grenegard, M., and Bengtsson, T. (2010). Toll-like receptor 2 stimulation of platelets is mediated by purinergic $\mathrm{P} 2 \mathrm{X} 1$-dependent $\mathrm{Ca}^{2+}$ mobilisation, cyclooxygenase and purinergic $\mathrm{P}_{2} \mathrm{Y}_{1}$ and $\mathrm{P}_{2} \mathrm{Y}_{12}$ receptor activation. Thromb. Haemost. 103, 398-407. doi: 10.1160/TH0907-0442

Kawate, T., Michel, J. C., Birdsong, W. T., and Gouaux, E. (2009). Crystal structure of the ATP-gated $\mathrm{P}_{2} \mathrm{X}_{4}$ ion channel in the closed state. Nature 460, 592-598. doi: 10.1038/nature 08198

Knight, G. E., Bodin, P., de Groat, W. C., and Burnstock, G. (2002). ATP is released from guinea pig ureter epithelium on distension. Am. J. Physiol. Renal Physiol. 282, F281-F288. doi: 10.1152/ajprenal.00293.2000

Knutsen, L. J. S., and Murray, T. F. (1997). "Adenosine and ATP in epilepsy," in Purinergic Approaches in Experimental Therapeutics, eds K. A. Jacobson and M. F. Jarvis (New York, NY: Wiley-Liss), 423-447.

Komarova, S. V., Dixon, S. J., and Sims, S. M. (2001). Osteoclast ion channels: potential targets for antiresorptive drugs. Curr. Pharm. Des. 7, 637-654. doi: $10.2174 / 1381612013397799$

Lalo, U., Verkhratsky, A., Burnstock, G., and Pankratov, Y. (2012). P2X receptormediated synaptic transmission. WIREs Membrane Transport and Signaling 1 , 297-309. doi: 10.1002/wmts.28

Lammas, D. A., Stober, C., Harvey, C. J., Kendrick, N., Panchalingam, S., and Kumararatne, D. S. (1997). ATP-induced killing of mycobacteria by human macrophages is mediated by purinergic $\mathrm{P} 2 \mathrm{Z}\left(\mathrm{P}_{2} \mathrm{X}_{7}\right)$ receptors. Immunity 7 , 433-444. doi: 10.1016/S1074-7613(00)80364-7

Lazarowski, E. R. (2012). Vesicular and conductive mechanisms of nucleotide release. Purinergic Signal. 8, 359-373. doi: 10.1007/s11302-012-9304-9

Lazarowski, E. R., Sesma, J. I., Seminario-Vidal, L., and Kreda, S. M. (2011). Molecular mechanisms of purine and pyrimidine nucleotide release. $A d v$ Pharmacol. 61, 221-261. doi: 10.1016/B978-0-12-385526-8.00008-4

Lecut, C., Frederix, K., Johnson, D. M., Deroanne, C., Thiry, M., Faccinetto, C., et al. (2009). $\mathrm{P} 2 \mathrm{X}_{1}$ ion channels promote neutrophil chemotaxis through Rho kinase activation. J. Immunol. 183, 2801-2809. doi: 10.4049/jimmunol. 0804007

Lee, H. Y., Bardini, M., and Burnstock, G. (2000). Distribution of P2X receptors in the urinary bladder and the ureter of the rat. J. Urol. 163, 2002-2007. doi: $10.1016 / S 0022-5347(05) 67618-5$
Lemaire, I., Falzoni, S., Leduc, N., Zhang, B., Pellegatti, P., Adinolfi, E., et al. (2006). Involvement of the purinergic $\mathrm{P}_{2} \mathrm{X}_{7}$ receptor in the formation of multinucleated giant cells. J Immunol. 177, 7257-7265.

Lemaire, I., and Leduc, N. (2004). Purinergic $\mathrm{P}_{2} \mathrm{X}_{7}$ receptor function in lung alveolar macrophages: pharmacologic characterisation and bidirectional regulation by Th1 and Th2 cytokines. Drug Dev. Res. 59, 118-127. doi: 10.1002/ddr.10209

Lewis, C., Neidhart, S., Holy, C., North, R. A., Buell, G., and Surprenant, A. (1995). Coexpression of $\mathrm{P} 2 \mathrm{X}_{2}$ and $\mathrm{P} 2 \mathrm{X}_{3}$ receptor subunits can account for ATP-gated currents in sensory neurons. Nature 377, 432-435. doi: 10.1038/377432a0

Lu, S. H., Fraser, M. O., Chancellor, M. B., Cheng, C. L., and de Groat, W. C. (2002). Voiding dysfunction and purinergic mechanisms in awake chronic spinal cord injured (SCI) rats. Soc. Neurosci. Program No. 68.6.2002.

Lucae, S., Salyakina, D., Barden, N., Harvey, M., Gagné, B., Labbé, M., et al. (2006) $\mathrm{P} 2 \mathrm{RX} 7$, a gene coding for a purinergic ligand-gated ion channel, is associated with major depressive disorder. Hum. Mol. Genet. 15, 2438-2445. doi: $10.1093 / \mathrm{hmg} / \mathrm{ddl} 166$

Lustig, K. D., Shiau, A. K., Brake, A. J., and Julius, D. (1993). Expression cloning of an ATP receptor from mouse neuroblastoma cells. Proc. Natl. Acad. Sci. USA 90 5113-5117. doi: 10.1073/pnas.90.11.5113

Mantuano-Barradas, M., Henriques-Pons, A., Araújo-Jorge, T. C., Di Virgilio, F., Coutinho-Silva, R., and Persechini, P. M. (2003). Extracellular ATP induces cell death in $\mathrm{CD} 4+/ \mathrm{CD} 8+$ double-positive thymocytes in mice infected with Trypanosoma cruzi. Microbes. Infect. 5, 1363-1371. doi: 10.1016/j.micinf.2003.09.017

McGaraughty, S., Chu, K. L., Namovic, M. T., Donnelly-Roberts, D. L., Harris, R. R., Zhang, X. F., et al. (2007). P2X7-related modulation of pathological nociception in rats. Neuroscience 146, 1817-1828. doi: 10.1016/j.neuroscience.2007.03.035

McLarnon, J. G., Ryu, J. K., Walker, D. G., and Choi, H. B. (2006). Upregulated expression of purinergic $\mathrm{P}_{2} \mathrm{X}_{7}$ receptor in Alzheimer disease and amyloid-b peptide-treated microglia and in peptide-injected rat hippocampus. J. Neuropathol. Exp. Neurol. 65, 1090-1097. doi: 10.1097/01.jnen.0000240470.97295.d3

Mizumoto, N., Mummert, M. E., Shalhevet, D., and Takashima, A. (2003). Keratinocyte ATP release assay for testing skin-irritating potentials of structurally diverse chemicals. J. Invest. Dermatol. 121, 1066-1072. doi: 10.1046/j.1523-1747.2003.12558.x

Mulryan, K., Gitterman, D. P., Lewis, C. J., Vial, C., Leckie, B. J., Cobb, A. L., et al. (2000). Reduced vas deferens contraction and male infertility in mice lacking $\mathrm{P} 2 \mathrm{X}_{1}$ receptors. Nature 403, 86-89. doi: 10.1038/47495

Musa, H., Tellez, J. O., Chandler, N. J., Greener, I. D., Maczewski, M., Mackiewicz, U., et al. (2009). P2 purinergic receptor mRNA in rat and human sinoatrial node and other heart regions. Naunyn Schmiedebergs Arch. Pharmacol. 379, 541-549. doi: 10.1007/s00210-009-0403-2

Narcisse, L., Scemes, E., Zhao, Y., Lee, S. C., and Brosnan, C. F. (2005). The cytokine IL-1b transiently enhances $\mathrm{P}_{2} \mathrm{X}_{7}$ receptor expression and function in human astrocytes. Glia 49, 245-258. doi: 10.1002/glia.20110

Nicke, A., Baumert, H. G., Rettinger, J., Eichele, A., Lambrecht, G., Mutschler, E., et al. (1998). P2X $\mathrm{X}_{1}$ and $\mathrm{P}_{2} \mathrm{X}_{3}$ receptors form stable trimers: a novel structural motif of ligand-gated ion channels. $E M B O ~ J .17,3016-3028$. doi: 10.1093/emboj/17.11.3016

North, R. A. (2002). Molecular physiology of P2X receptors. Physiol. Rev. 82, 1013-1067.

Nurden, A. T. (2007). Does ATP act through $\mathrm{P} 2 \mathrm{X}_{1}$ receptors to regulate platelet activation and thrombus formation? J. Thromb. Haemost. 5, 907-909. doi 10.1111/j.1538-7836.2007.02456.x

O’Reilly, B. A., Kosaka, A. H., Knight, G. E., Chang, T. K., Ford, A. P. D. W., Rymer, J. M., et al. (2002). P2X receptors and their role in female idiopathic detrusor instability. J. Urol. 167, 157-164. doi: 10.1016/S0022-5347(05)65403-1

Orriss, I. R., Burnstock, G., and Arnett, T. R. (2010). Purinergic signalling and bone remodelling. Curr. Op. Pharmacol. 10, 322-330. doi: 10.1016/j.coph.2010.01.003

Orriss, I. R., Key, M. L., Brandao-Burch, A., Burnstock, G., and Arnett, T. R. (2012). The regulation of osteoblast function and bone mineralisation by extracellular nucleotides: the role of P2X receptors. Bone 51, 389-400. doi: 10.1016/j.bone.2012.06.013

Oses, J. P. (2006). Modification by kainate-induced convulsions of the density of presynaptic P2X receptors in the rat hippocampus. Purinergic Signal. 2, 252-253. 
Panenka, W., Jijon, H., Herx, L. M., Armstrong, J. N., Feighan, D., Wei, T., et al. (2001). P2X7-like receptor activation in astrocytes increases chemokine monocyte chemoattractant protein-1 expression via mitogen-activated protein kinase. J. Neurosci. 21, 7135-7142.

Parvathenani, L. K., Tertyshnikova, S., Greco, C. R., Roberts, S. B., Robertson, B., and Posmantur, R. (2003). P2 $\mathrm{X}_{7}$ mediates superoxide production in primary microglia and is up-regulated in a transgenic mouse model of Alzheimer's disease. J. Biol. Chem. 278, 13309-13317. doi: 10.1074/jbc.M209478200

Pintor, J. (2006). New perspectives in ocular pharmacology: nucleotides as therapeutic agents. An R Acad Nac Farm 72, 519-538.

Pintor, J., Peral, A., Pelaez, T., Carracedo, G., Bautista, A., and Hoyle, C. H. (2003). Nucleotides and dinucleotides in ocular physiology: new possibilities of nucleotides as therapeutic agents in the eye. Drug Dev. Res. 59, 136-145. doi: $10.1002 / \mathrm{ddr} .10193$

Queiroz, G., Talaia, C., and Gonçalves, J. (2003). ATP modulates noradrenaline release by activation of inhibitory P2Y receptors and facilitatory P2X receptors in the rat vas deferens. J. Pharmacol. Exp. Ther. 307, 809-815. doi: 10.1124/jpet.103.054809

Ralevic, V., and Burnstock, G. (1998). Receptors for purines and pyrimidines. Pharmacol. Rev. 50, 413-492.

Raouf, R., Chabot-Dore, A. J., Ase, A. R., Blais, D., and Seguela, P. (2007). Differential regulation of microglial $\mathrm{P}_{2} \mathrm{X}_{4}$ and $\mathrm{P} 2 \mathrm{X}_{7}$ ATP receptors following LPS-induced activation. Neuropharmacology 53, 496-504. doi: 10.1016/j.neuropharm.2007.06.010

Rapaport, E. (1983). Treatment of human tumor cells with ADP or ATP yields arrest of growth in the S phase of the cell cycle. J. Cell. Physiol. 114, 279-283. doi: $10.1002 /$ jcp. 1041140305

Rappold, P. M., Lynd-Balta, E., and Joseph, S. A. (2006). P2X 7 receptor immunoreactive profile confined to resting and activated microglia in the epileptic brain. Brain Res. 1089, 171-178. doi: 10.1016/j.brainres.2006.03.040

Roberts, V. H., Webster, R. P., Brockman, D. E., Pitzer, B. A., and Myatt, L. (2007). Post-translational modifications of the $\mathrm{P}_{2} \mathrm{X}_{4}$ purinergic receptor subtype in the human placenta are altered in preeclampsia. Placenta 28, 270-277. doi: 10.1016/j.placenta.2006.04.008

Rong, W., and Burnstock, G. (2004). Activation of ureter nociceptors by exogenous and endogenous ATP in guinea pig. Neuropharmacology 47, 1093-1101. doi: 10.1016/j.neuropharm.2004.08.003

Rong, W., Burnstock, G., and Spyer, K. M. (2000). P2X purinoceptor-mediated excitation of trigeminal lingual nerve terminals in an in vitro intra-arterially perfused rat tongue preparation. J. Physiol. 524, 891-902. doi: 10.1111/j.14697793.2000.00891.x

Rossato, M., La Sala, G. B., Balasini, M., Taricco, F., Galeazzi, C., Ferlin, A., et al. (1999). Sperm treatment with extracellular ATP increases fertilization rates in in-vitro fertilization for male factor infertility. Hum. Reprod. 14, 694-697. doi: 10.1093/humrep/14.3.694

Ryten, M., Yang, S. Y., Dunn, P. M., Goldspink, G., and Burnstock, G. (2004). Purinoceptor expression in regenerating skeletal muscle in the $\mathrm{mdx}$ mouse model of muscular dystrophy and in satellite cell cultures. FASEB J. 18, 1404-1406. doi: 10.1096/fj.03-1175fje

Schulman, E. S., Glaum, M. C., Post, T., Wang, Y., Raible, D. G., Mohanty, J., et al. (1999). ATP modulates anti-IgE-induced release of histamine from human lung mast cells. Am. J. Respir. Cell Mol. Biol. 20, 530-537. doi: 10.1165/ajrcmb.20.3.3387

Schwiebert, E. M., Wallace, D. P., Braunstein, G. M., King, S. R., Peti-Peterdi, J., Hanaoka, K., et al. (2002). Autocrine extracellular purinergic signaling in epithelial cells derived from polycystic kidneys. Am. J. Physiol. Renal Physiol. 282, F763-F775. doi: 10.1152/ajprenal.0337.2000

Shabbir, M., Ryten, M., Thompson, C. S., Mikhailidis, D. P., and Burnstock, G. (2008a). Purinergic receptor-mediated effects of ATP in high-grade bladder cancer. BJU Int. 101, 106-112. doi: 10.1111/j.1464-410X.2007.07286.x

Shabbir, M., Thompson, C. S., Jarmulowicz, M., Mikhailidis, D. P., and Burnstock, G. (2008b). Effect of extracellular ATP on the growth of hormone refractory prostate cancer in vivo. BJU Int. 102, 108-112. doi: 10.1111/j.1464410X.2008.07578.x

Shen, J. B., Cronin, C., Sonin, D., Joshi, B. V., Gongora Nieto, M., Harrison, D., et al. (2007). P2X purinergic receptor-mediated ionic current in cardiac myocytes of calsequestrin model of cardiomyopathy: implications for the treatment of heart failure. Am. J. Physiol. Heart Circ. Physiol. 292, H1077-H1084. doi: 10.1152/ajpheart.00515.2006
Shinoda, M., Feng, B., and Gebhart, G. F. (2009). Peripheral and central $\mathrm{P}_{2} \mathrm{X}_{3}$ receptor contributions to colon mechanosensitivity and hypersensitivity in the mouse. Gastroenterology 137, 2096-2104. doi: 10.1053/j.gastro.2009. 06.048

Silinsky, E. M., Gerzanich, V., and Vanner, S. M. (1992). ATP mediates excitatory synaptic transmission in mammalian neurones. Br. J. Pharmacol. 106, 762-763. doi: 10.1111/j.1476-5381.1992.tb14408.x

Stevenson, R. O., Taylor, R. M., Wiley, J. S., and Sluyter, R. (2009). The P2X receptor mediates the uptake of organic cations in canine erythrocytes and mononuclear leukocytes: comparison to equivalent human cell types. Purinergic Signal. 5, 385-394. doi: 10.1007/s11302-009-9163-1

Stojilkovic, S. S., He, M. L., Koshimizu, T. A., Balik, A., and Zemkova, H. (2010). Signaling by purinergic receptors and channels in the pituitary gland. Mol. Cell. Endocrinol. 314, 184-191. doi: 10.1016/j.mce.2009.05.008

Sugiyama, T., Kobayashi, M., Kawamura, H., Li, Q., Puro, D. G., and Kobayshi, M. (2004). Enhancement of P2X7-induced pore formation and apoptosis: an early effect of diabetes on the retinal microvasculature. Invest. Ophthalmol. Vis. Sci. 45, 1026-1032. doi: 10.1167/iovs.03-1062

Takenouchi, T., Iwamaru, Y., Imamura, M., Kato, N., Sugama, S., Fujita, M., et al. (2007). Prion infection correlates with hypersensitivity of P2X7 nucleotide receptor in a mouse microglial cell line. FEBS Lett. 581, 3019-3026. doi: 10.1016/j.febslet.2007.05.057

Tempest, H. V., Dixon, A. K., Turner, W. H., Elneil, S., Sellers, L. A., and Ferguson, D. R. (2004). P2X and P2X receptor expression in human bladder urothelium and changes in interstitial cystitis. BJU Int. 93, 1344-1348. doi: 10.1111/j.1464410X.2004.04858.x

Tian, G. F., Azmi, H., Takano, T., Xu, Q., Peng, W., Lin, J., et al. (2005). An astrocytic basis of epilepsy. Nat. Med. 11, 973-981. doi: 10.1038/nm1277

Trang, T., Beggs, S., and Salter, M. W. (2012). ATP receptors gate microglia signaling in neuropathic pain. Exp. Neurol. 234, 354-361. doi: 10.1016/j.expneurol.2011.11.012

Trang, T., and Salter, M. W. (2012). P2X4 purinoceptor signaling in chronic pain. Purinergic Signal. 8, 621-628. doi: 10.1007/s11302-012-9306-7

Tsuda, M., Shigemoto-Mogami, Y., Koizumi, S., Mizokoshi, A., Kohsaka, S., Salter, M. W., et al. (2003). P2X $\mathrm{X}_{4}$ receptors induced in spinal microglia gate tactile allodynia after nerve injury. Nature 424, 778-783. doi: 10.1038/nature 01786

Tsuda, M., Tozaki-Saitoh, H., and Inoue, K. (2010). Pain and purinergic signaling. Brain Res. Rev. 63, 222-232. doi: 10.1016/j.brainresrev.2009.11.003

Turner, C., Ramesh, B., Srai, S. K. S., Burnstock, G., and Unwin, R. (2004). Altered P2 receptor expression in the Han:SPRD cy $/^{+}$rat, a model of autosomal dominant polycystic kidney disease. Cells Tiss. Org. 178, 168-179. doi: $10.1159 / 000082247$

Turner, C. M., Tam, F., Lai, P.-C., Tarzi, R. M., Burnstock, G., Pusey, C. D., et al. (2007). Increased expression of the pro-apoptotic ATP-sensitive P2X 7 receptor in experimental and human glomerulonephritis. Nephrol. Dial. Transpl. 22, 386-395. doi: 10.1093/ndt/gfl589

Unwin, R. J., Bailey, M. A., and Burnstock, G. (2003). Purinergic signaling along the renal tubule: the current state of play. News Physiol. Sci. 18, 237-241. doi: 10.1152/nips.01436.2003

Valera, S., Hussy, N., Evans, R. J., Adani, N., North, R. A., Surprenant, A., et al. (1994). A new class of ligand-gated ion channel defined by $P_{2 X}$ receptor for extra-cellular ATP. Nature 371, 516-519. doi: 10.1038/371516a0

Vanderwinden, J. M., Timmermans, J. P., and Schiffmann, S. N. (2003). Glial cells, but not interstitial cells, express $\mathrm{P} 2 \mathrm{X} 7$, an ionotropic purinergic receptor, in rat gastrointestinal musculature. Cell Tiss. Res. 312, 149-154. doi: 10.1007/s00441003-0716-2

Vlaskovska, M., Kasakov, L., Rong, W., Bodin, P., Bardini, M., Cockayne, D. A., et al. (2001). P2X $\mathrm{X}_{3}$ knockout mice reveal a major sensory role for urothelially released ATP. J. Neurosci. 21, 5670-5677.

Volonté, C., and Burnstock, G. (2012). Editorial: pharmacology and therapeutic activity of purinergic drugs for disorders of the nervous system. CNS Neurol. Disord. Drug Targ. 11, 649-651. doi: 10.2174/187152712803581119

Vonend, O., Turner, C., Chan, C. M., Loesch, A., Dell'Anna, G. C., Srai, S. K., et al. (2004). Glomerular expression of the ATP-sensitive $\mathrm{P}_{2} \mathrm{X}_{7}$ receptor in diabetic and hypertensive rat models. Kidney Int. 66, 157-166. doi: 10.1111/j.15231755.2004.00717.x

Wang, J. C., Raybould, N. P., Luo, L., Ryan, A. F., Cannell, M. B., Thorne, P. R., et al. (2003). Noise induces up-regulation of $\mathrm{P}_{2} \mathrm{X}_{2}$ receptor subunit of ATP-gated ion 
channels in the rat cochlea. Neuroreport 14, 817-823. doi: 10.1097/00001756200305060-00008

Webb, T. E., Simon, J., Krishek, B. J., Bateson, A. N., Smart, T. G., King, B. F., et al. (1993). Cloning and functional expression of a brain G-protein-coupled ATP receptor. FEBS Lett. 324, 219-225. doi: 10.1016/0014-5793(93)81397-I

White, N., and Burnstock, G. (2006). P2 receptors and cancer. Trends Pharmacol. Sci. 27, 211-217. doi: 10.1016/j.tips.2006.02.004

White, N., Butler, P. E. M., and Burnstock, G. (2005a). Human melanomas express functional $\mathrm{P}_{2} \mathrm{X}_{7}$ receptors. Cell Tiss. Res. 321, 411-418. doi: 10.1007/s00441005-1149-x

White, N., Ryten, M., Clayton, E., Butler, P., and Burnstock, G. (2005b). P2Y purinergic receptors regulate the growth of human melanomas. Cancer Lett. 224, 81-91. doi: 10.1016/j.canlet.2004.11.027

Wildman, S. S., Kang, E. S., and King, B. F. (2009). ENaC, renal sodium excretion and extracellular ATP. Purinergic Signal. 5, 481-489. doi: 10.1007/s11302-0099150-6

Wirkner, K., Sperlagh, B., and Illes, P. (2007). P2X 3 receptor involvement in pain states. Mol. Neurobiol. 36, 165-183. doi: 10.1007/s12035-007-0033-y

Wynn, G., Bei, M., Ruan, H.-Z., and Burnstock, G. (2004). Purinergic component of mechanosensory transduction is increased in a rat model of colitis. Am. J. Physiol. Gastrointest. Liver Physiol. 287, G647-G657. doi: 10.1152/ajpgi.00020.2004

Wynn, G., Rong, W., Xiang, Z., and Burnstock, G. (2003). Purinergic mechanisms contribute to mechanosensory transduction in the rat colorectum. Gastroenterology 125, 1398-1409. doi: 10.1016/j.gastro.2003.07.008

Xiang, Z., Bo, X., and Burnstock, G. (1999). P2X receptor immunoreactivity in the rat cochlea, vestibular ganglion and cochlear nucleus. Hear. Res. 128, 190-196. doi: $10.1016 /$ S0378-5955(98)00208-1

Xiang, Z., and Burnstock, G. (2004). P2X $\mathrm{X}_{2}$ and $\mathrm{P} 2 \mathrm{X}_{3}$ purinoceptors in the rat enteric nervous system. Histochem. Cell Biol. 121, 169-179. doi: 10.1007/s00418004-0620-1

Xu, G. Y., Shenoy, M., Winston, J. H., Mittal, S., and Pasricha, P. J. (2008). $\mathrm{P} 2 \mathrm{X}$ receptor-mediated visceral hyperalgesia in a rat model of chronic visceral hypersensitivity. Gut 57, 1230-1237. doi: 10.1136/gut.2007.134221
Yegutkin, G. G. (2008). Nucleotide- and nucleoside-converting ectoenzymes: Important modulators of purinergic signalling cascade. Biochim. Biophys. Acta 1783, 673-694. doi: 10.1016/j.bbamcr.2008.01.024

Yiangou, Y., Facer, P., Baecker, P. A., Ford, A. P., Knowles, C. H., Chan, C. L., et al. (2001). ATP-gated ion channel $\mathrm{P}_{2} \mathrm{X}_{3}$ is increased in human inflammatory bowel disease. Neurogastroenterol. Motil. 13, 365-369. doi: 10.1046/j.13652982.2001.00276.x

Zhao, D. M., Xue, H. H., Chida, K., Suda, T., Oki, Y., Kanai, M., et al. (2000). Effect of erythromycin on ATP-induced intracellular calcium response in A549 cells. Am. J. Physiol. Lung Cell. Mol. Physiol. 278, L726-L736.

Zimmermann, H. (2006). Nucleotide signaling in nervous system development. Pflugers Arch. 452, 573-588. doi: 10.1007/s00424-0060067-4

Zsembery, A., Boyce, A. T., Liang, L., Peti-Peterdi, J., Bell, P. D., and Schwiebert, E. M. (2003). Sustained calcium entry through P2X nucleotide receptor channels in human airway epithelial cells. J. Biol. Chem. 278, 13398-13408. doi: 10.1074/jbc.M212277200

Conflict of Interest Statement: The author declares that the research was conducted in the absence of any commercial or financial relationships that could be construed as a potential conflict of interest.

Received: 19 September 2013; paper pending published: 10 October 2013; accepted: 04 November 2013; published online: 21 November 2013.

Citation: Burnstock G (2013) Introduction and perspective, historical note. Front. Cell. Neurosci. 7:227. doi: 10.3389/fncel.2013.00227

This article was submitted to the journal Frontiers in Cellular Neuroscience.

Copyright (ㅇ) 2013 Burnstock. This is an open-access article distributed under the terms of the Creative Commons Attribution License (CC BY). The use, distribution or reproduction in other forums is permitted, provided the original author(s) or licensor are credited and that the original publication in this journal is cited, in accordance with accepted academic practice. No use, distribution or reproduction is permitted which does not comply with these terms. 